\title{
Uma coleção de arquitetura moderna: imagem e narratividade no catálogo latino-americano de Henry-Russell Hitchcock (1955)'
}

A modern architecture collection: Image and narrativity in Henry-Russell Hitchcock's catalog on Latin America (1955)

hitps://doi.org/10.1590/1982-02672021v29e62

\section{CLAUDIA COSTA CABRAL ${ }^{2}$}

https://orcid.org/0000-0003-0079-1861

Universidade Federal do Rio Grande do Sul / Porto Alegre, RS, Brasil

RESUMO: Os edifícios são colecionáveis? Houve quem colecionasse projetos, como o casal Tremaine, para quem Niemeyer e Johnson projetaram casas nunca construídas; certas exposições incorporaram protótipos arquitetônicos, como a casa que Brever levantou no jardim do MoMA em 1949. Mas na grande maioria das vezes, as obras de arquitetura entram nos museus e na historiografia através de algo que as representa. Essas representações - fotografias, desenhos - geralmente compõem catálogos que, de certa maneira, desfrutam de uma vida independente das exposições que os originaram e superam-nas em longevidade. Latin American Architecture since 1945, catálogo decorrente da exposição homônima organizada por Henry-Russell Hitchcock para o MoMA em 1955, é hoje amplamente reconhecido como peça fundamental na construção historiográfica da arquitetura moderna latino-americana, bem como ○ Brazil Builds de Philip Goodwin (1943). Os catálogos de arquitetura são produtos bibliográficos onde as imagens têm papel preponderante sobre os textos. Entram na categoria da coleção de figuras ou do álbum fotográfico. Contudo, não obstante a prioridade da imagem sobre a palavra, o catálogo constitui, também, uma narrativa. $\bigcirc$ objetivo deste texto é interrogar a condição narrativa própria do catálogo como coleção de arquitetura, como álbum fotográfico, em suas correlações com os métodos da historiografia e com a formação do conceito de arquitetura moderna, através de Latin American Architecture since 1945.

\begin{abstract}
1. Uma versão inicial deste texto foi apresentada em 2010, como parte da Sessão Temática "Coleções de Arquitetura" do I ENANPARQ - Encontro Nacional da Associação Nacional de Pesquisa e Pós-Graduação em Arquitetura e Urbanismo (Rio de Janeiro, UFRJ, UFF, ANPARQ, 2010), proposta e coordenada por Gustavo da Rocha Peixoto. Desde então, avanços importantes no conhecimento do tema foram produzidos. Destacam-se, especialmente, a exposição "Latin American in Construction. Architecture 1955-1980", curada por Berry Bergdoll, Carlos Eduardo Comas, Jorge Francisco Liernur e Patricio del Real (2015); a investigação doutoral de Patricio del Real (2011; 2012); os textos de Horacio Torrent (2014, $2015,2017)$. A presente versão comporta uma ampliação substancial da discussão inicialmente formulada, favorecida pela oportunidade de consultar os arquivos do MoMA (The Museum of Modern Art, New York), com o apoio do Conselho Nacional de Desenvolvimento Científico e Tecnológico (CNPq).
\end{abstract}


2. Arquiteta e mestre pela Universidade Federal do Rio Grande do Sul (UFRGS). Doutora em Teoria e História da Arquitetura pela Universitat Politecnica de Catalunya. Atualmente é professora titular do Departamento de Arquitetura da UFRGS, atuando na graduação e na pós-graduação; pesquisadora nível 1D do CNPq, líder do Grupo de Pesquisa Estudos de Arquitetura Moderna Latino-americana. E-mail: <claudiacostacabral@gmail. com>.
PALAVRAS-CHAVE: Coleção. Narrativa. Arquitetura moderna. América Latina.

ABSTRACT: Are buildings collectible? Some people collected projects, like the Tremaine couple, for whom Niemeyer and Johnson designed houses that they never built; some exhibitions incorporated architectural prototypes, such as the house installed by Brever in MoMA's garden in 1949. But in most cases, works of architecture enter museums (and historiography) by their representations. These representations - photographs, drawings - usually compose catalogs that, in a way, enjoy a life independent from their exhibitions of origin, whose longevity they surpass. Latin American Architecture Since 1945, the catalog of the homonymous exhibition organized by Henry-Russell Hitchcock for MoMA in 1955, is now widely recognized as a central piece in the historiographical construction of Latin American modern architecture, like Brazil Builds by Philip Goodwin (1943). Architectural catalogs are bibliographic products where pictures have a predominant role over texts. They fall into the category of the picture collection, or the photographic album. But despite the priority of image over word, the catalog is also a narrative. The purpose of this text is to examine the intrinsic narrative condition of the catalog as a photographic album and as an architecture collection, in its correlations with the historiographic methods and with the formation of the modern architecture concept, by using Latin American Architecture Since 1945.

KEYWORDS: Collection. Narrative. Modern architecture. Latin America. 
O que é uma coleção? No sentido mais abrangente do termo, uma coleção é um conjunto de objetos de natureza similar, que mantêm entre si algum tipo de relação (Figura 1). Num sentido menos genérico, uma coleção é um conjunto de objetos que têm algum valor, afetivo ou intelectual, para determinados indivíduos ou grupos (Figura 2). Num terceiro sentido, ainda mais restrito, uma coleção é um conjunto de objetos que a sociedade considera notáveis e que merecem ser separados dos demais e preservados, geralmente no âmbito de arquivos e museus (Figura 3). Pomian define a "instituição coleção" como aquilo que deve precisamente satisfazer a esse critério, da reunião de objetos preciosos agrupados num mesmo lugar, temporária ou definitivamente, para que sejam protegidos e eventualmente exibidos. ${ }^{3}$ Esse lugar é o museu.

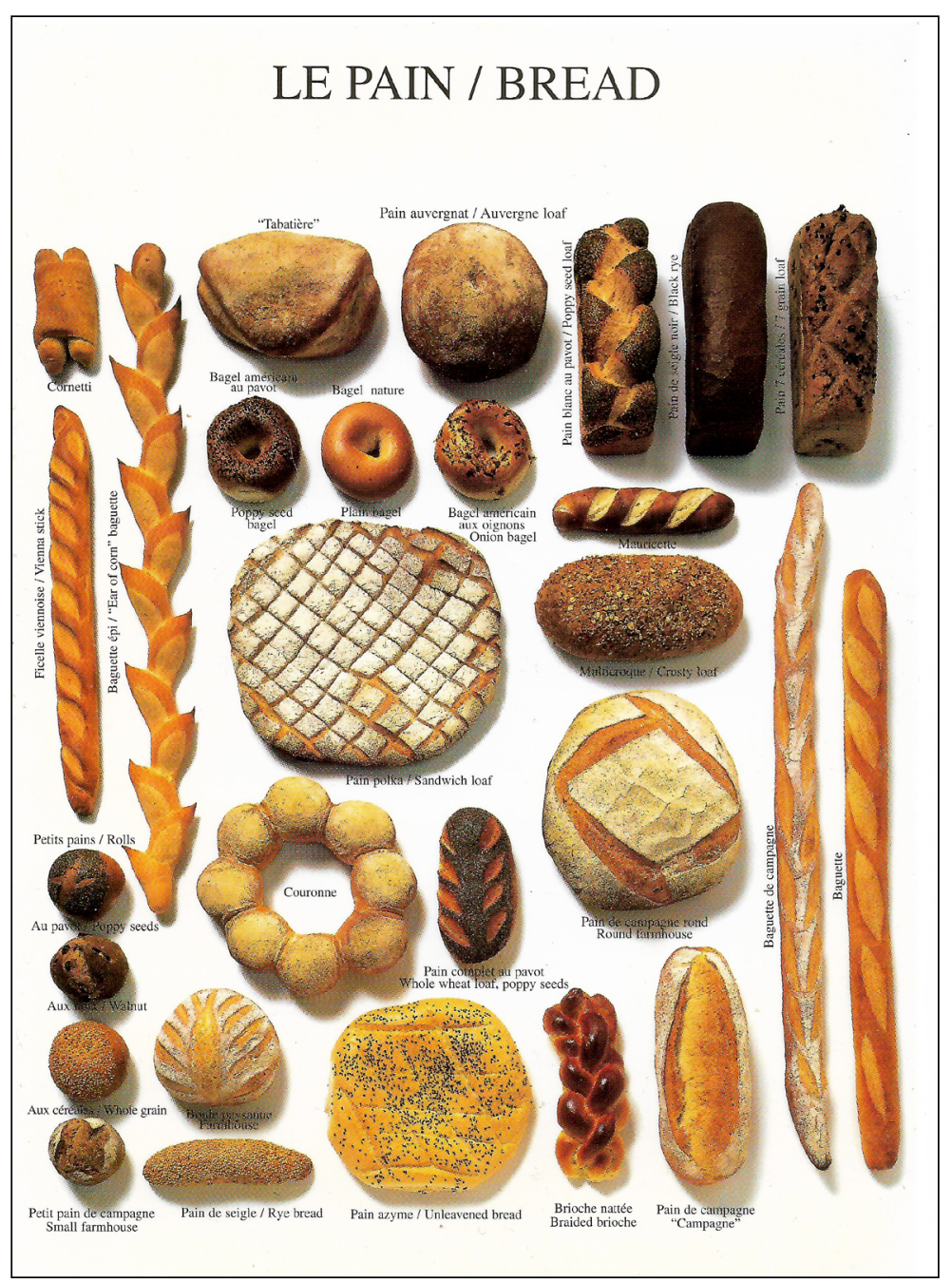

posto por Gustavo da Rocha-Peixoto no texto introdutório à Sessão Temática "Coleções de Arquitetura", a partir das definições de $\mathrm{Kr}$ zysztof Pomian (1990, p. 9).
Figura 1 - Conjunto de objetos de natureza similar. Cartão postal. Fonte: Atelier Nouvelles Images. Foto: $G$. Le Scanff; J. C. Mayer, 1997. 


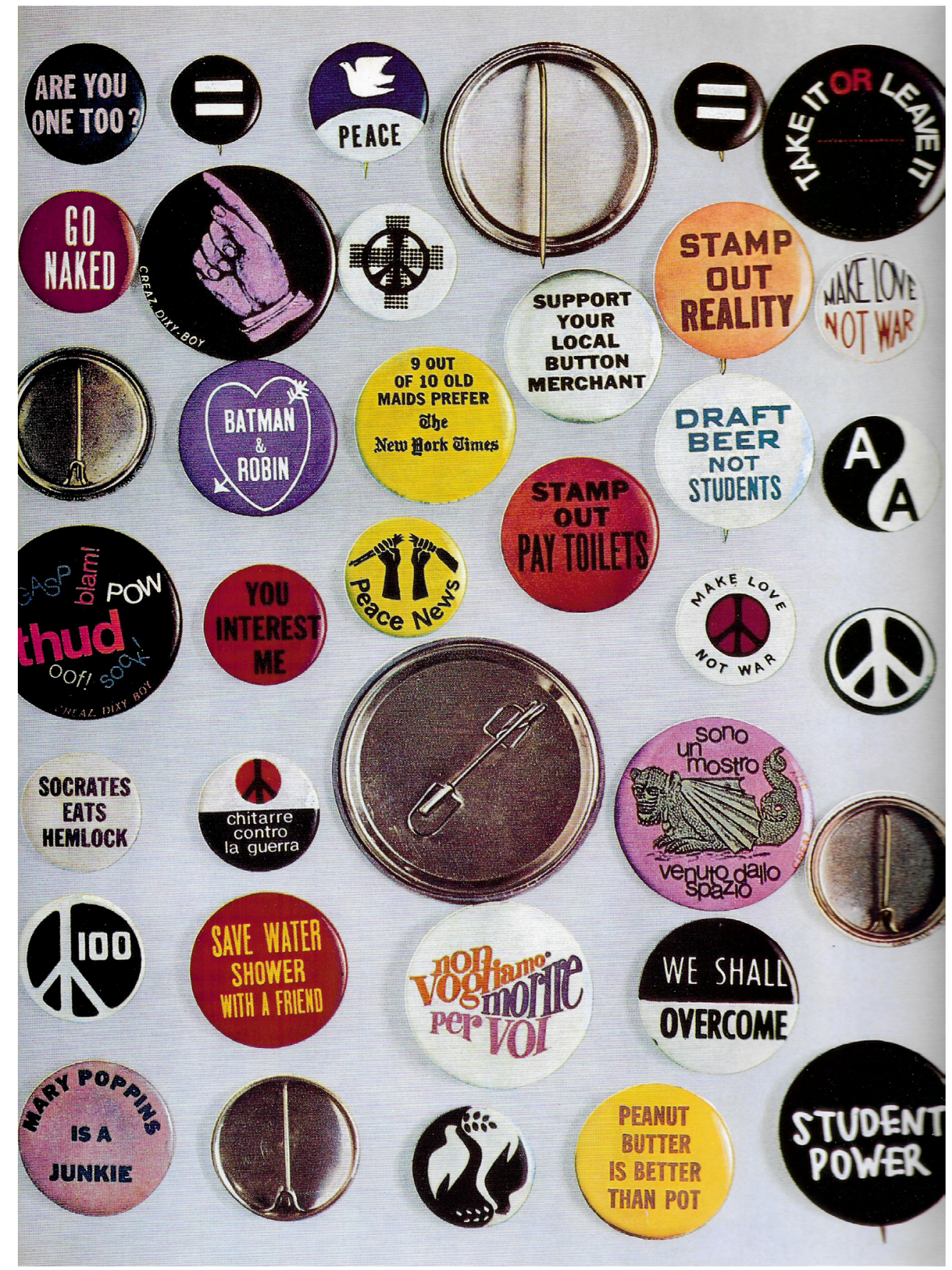

Figura 2 - Conjunto de objetos que possuem valor afetivo ou intelectual para indivíduos ou grupos. Fonte: Philippe Garner, Sixties Design, Taschen, 1996. 


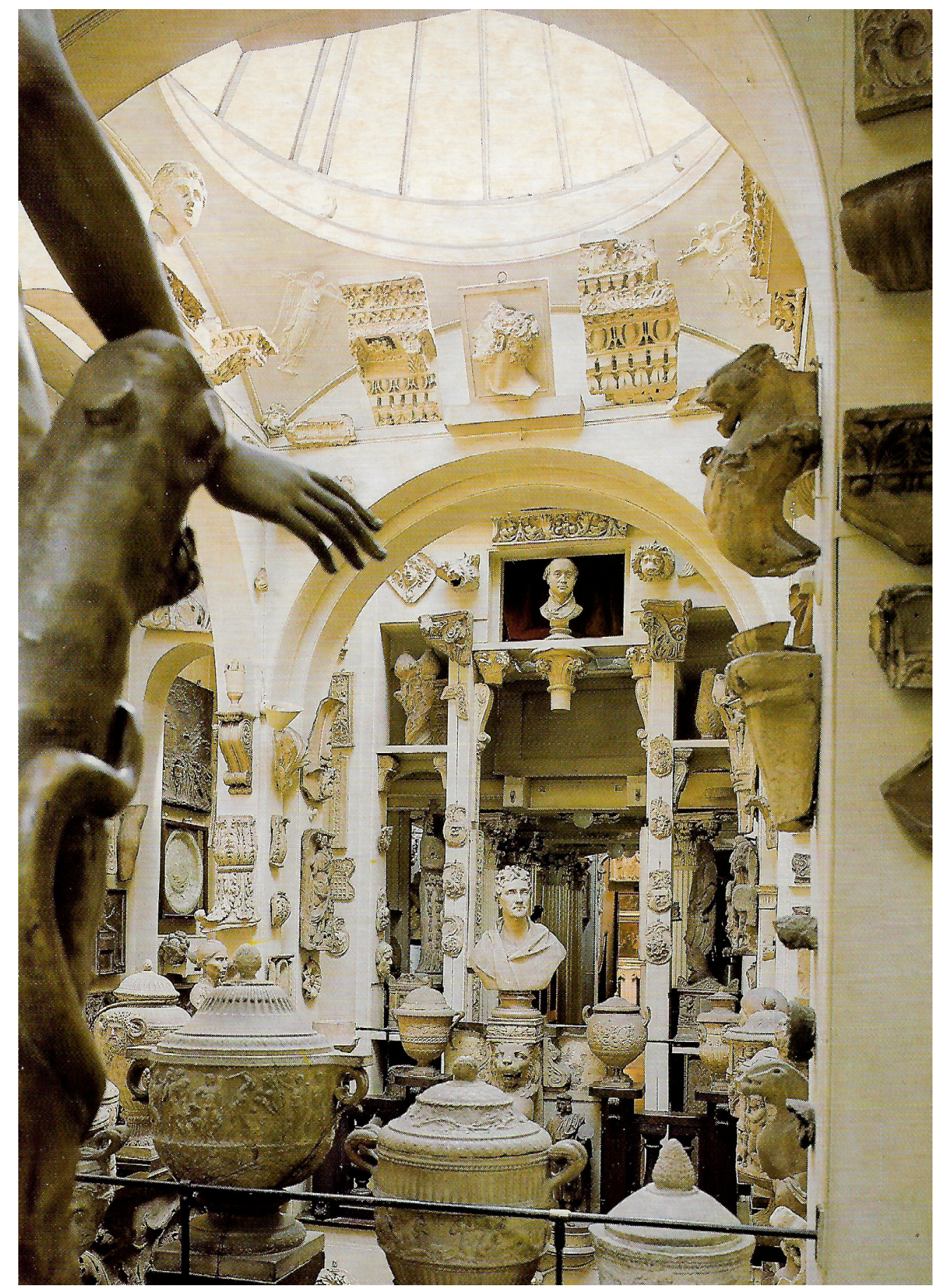

Figura 3 - Conjunto de objetos que a sociedade considera notáveis. Cartão postal. Fonte: Sir John Soane's Museum. The Trustees of Sir John Soane's Museum. 
4. O Museu Britânico, o primeiro museu público europeu, se fundou em 1753 a partir das amplas coleções privadas de Hans Sloane (1660-1753). Já o Museu do Louvre, convertido pela Revolução Francesa em 1793 em galeria pública nacional, teve seu ponto de partida no "desejo dos reis de França, desejo alimentado pela avidez, de formar uma coleção”, como afirmava René Huyghe, enquanto curador de pintura do Louvre; assim, sua "semente" foi a biblioteca formada por Carlos V (1338-1380), depois acrescida pela coleção de mestres da Renascença de Francisco I (1494-1547) (HUYGHE, 1967, p. 10). Também os tesouros do oriente (cuja pilhagem, no transcurso do século XIX, concorreu substancialmente para avultar os acervos dos grandes museus ocidentais) saíram de seus lugares de origem através da organização de coleções locais. No próprio Egito como explicava o diretor do Museu Egípcio do Cairo em 1969 - cerca de vinte grandes coleções foram formadas durante os primeiros anos do século XIX (coleções Anastasi, Athanasi, Drovetti, entre outras) e depois vendidas na Europa, "onde foram suprir museus em Leyden, Londres, Paris, Berlim e Turim" (RAHMAN, 1969, p. 9).

5. Preziosi (2009, p. 9).

6. Pomian (1984, p. 63).

7. Ibid., p. 62.

8. Ibid., p. 84 .

9. Conforme Pomian, "os museus substituem as igrejas enquanto locais onde todos os membros de uma sociedade podem comunicar na celebração de um mesmo culto". Ibid.

10. Pomian (1984, p. 62).
É bastante conhecida a relação entre a organização de grandes coleções privadas, inicialmente por parte da aristocracia e do clero, e a formação do museu como instituição pública. ${ }^{4}$ De certa maneira, o processo de criação do museu como instituição e sua considerável expansão a partir do século XIX, com a multiplicação e especialização dos museus, representam também o trânsito da ideia de coleção como um conjunto de objetos importantes para um grupo relativamente limitado de indivíduos, para a ideia de coleção como conjunto de objetos relevantes para um corpo social, por definição, abrangente. E, portanto, para o surgimento de um público, que pode ser compreendido como um corpo passível de expansão, o que passa a convocar, de parte do museu, a expectativa de assumir um rol formativo.

Uma aliança entre o museu e a historiografia pronto se estabelece. Como observa Donald Preziosi em The Art of Art History, a história da arte esteve sempre associada à museologia, num largo e tentativo processo de situar - "fixing-in-place" - uma série de objetos individuais com respeito "aos horizontes ideais de uma história (potencialmente universal) da forma artística" e consequente atribuição de um lugar para esses objetos num sistema completo de relações cronológicas e geográficas. ${ }^{5}$

Ao discorrer sobre a formação das coleções ao longo da história, Pomian menciona, antes das coleções dos príncipes, os mobiliários funerários, as oferendas, os presentes e os despojos, as relíquias e os objetos sagrados, que contrariamente aos tesouros principescos, não estão expostos ao olhar de outros seres humanos, mas sim de espectadores virtuais: os mortos e deuses a quem estão destinados, "situados num algures temporal ou espacial". ${ }^{6}$ Pomian vê no museu uma possibilidade de atualização dessa relação entre "o visível e o invisível". 7 No seu papel de atribuição de valor a objetos do passado, desempenhado em conjunto com a investigação historiográfica e auxiliado pelo desenvolvimento da conservação como atividade técnica, o museu surge como uma das "instituições cuja função consiste em criar um consenso sobre o modo de opor o visível ao invisível". ${ }^{8}$ É com base nesse consenso criado em torno da valorização desses objetos que o museu pode promover e garantir a sua salvaguarda. ${ }^{9}$

Mas, e quanto à arquitetura? São colecionáveis os edifícios? Pode o museu exercer um papel ativo, ainda que indireto, na preservação do patrimônio arquitetônico? A questão é especialmente pertinente quando se trata do patrimônio arquitetônico moderno, cuja valorização não se deve ao peso inequívoco do tempo, isło é, da antiguidade das obras, mas sim da difícil formação de consensos sobre valores artísticos e sociais, sempre passíveis de discussão. Na sua capacidade para "tornar visível"10 e para convocar a comunhão de amplas parcelas da sociedade em torno dessa visibilidade construída, pode o museu contribuir para a salvaguarda física e material do patrimônio arquitetônico? 
Certas exposições de arquitetura moderna incorporaram protótipos arquitetônicos, como a casa de Marcel Brever levantada no jardim do The Museum of Modern Art (MoMA) em Nova York em 1949." Houve quem colecionasse projetos, como o casal Burton e Emily Tremaine, para quem Oscar Niemeyer e Philip Johnson projetaram casas nunca construídas. ${ }^{12}$ Mas na imensa maioria das vezes, as obras de arquitetura entram nos museus e na historiografia através de algo que as representa: desenhos, fotografias, modelos, filmes. Grande parte dessas representações são bidimensionais - fotografias, desenhos - e passíveis de serem incorporadas a catálogos. De certa maneira, os catálogos desfrutam de uma vida independente das exposições que os originaram, e que, em longevidade, superam.

Latin American Architecture since 1945, catálogo decorrente da exposição homônima organizada por Henry-Russell Hitchcock para o MoMA em 1955 (Figura 4), é hoje amplamente reconhecido como peça fundamental na construção historiográfica da arquitetura moderna latino-americana, assim como o bem conhecido Brazil Builds: Architecture New and Old, 1652-1942 de Philip Goodwin, ${ }^{13}$ catálogo da mostra "Brazil Builds" (1943), também organizada pelo MoMA. ${ }^{14}$

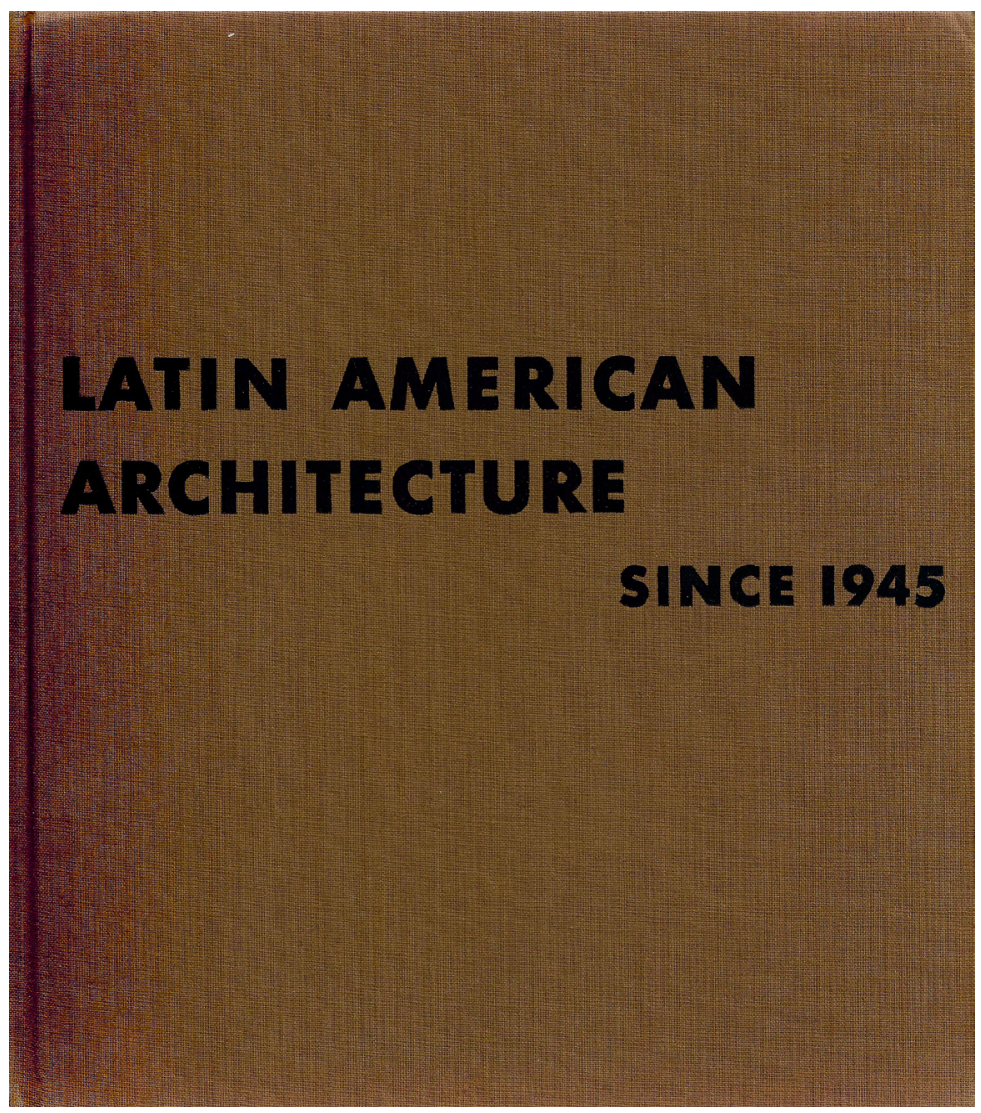

Figura 4 - Capa do Latin American Architecture since 1945. Fonte: Henry-Russell Hitchcock (1955).
11. Exposição "The House in the Museum Garden", The Museum of Modern Art, New York, 12 de abril a 30 de outubro de 1949 (BERGDOLL; CHRISTENSEN, 2008).

12. Oscar Niemeyer, Burton Tremaine House, Santa Barbara, California, 1947; Philip Johnson, Burton Tremaine House, Farmington, Connecticut, 1952.

13. Goodwin e Smith (1943).

14. Cf. Segawa (2005); Real (2007, 2012); Bergdoll (2012); Torrent (2014, 2015); Bergdoll, Comas, Liernur e Real (2015). 
15. Torrent (2015, p. 277).

16. Torrent (2015, p. 279); Real (2007, p. 99).

17. Real (2007, p. 107).

18. Torrent (2015, p. 279, p. 277).

19. Real (2007, p. 106).

20. Barthes (1980); Aumont (1993).
Contudo, a recepção contemporânea do catálogo Latin American Architecture since 1945, se coincidente quanto ao seu caráter fundante para uma possível "categoria" arquitetura moderna latino-americana -, adotando a expressão de Horacio Torrent -, não é precisamente convergente quanto à caracterização da perspectiva historiográfica e da posição assumida por Hitchcock a respeito da arquitetura moderna latino-americana. ${ }^{15}$ Patricio del Real e Horacio Torrent concordam em que o conjunto de obras apresentado manifesta uma considerável homogeneidade no plano material (o que, no âmbito deste texto, satisfaz uma das características de uma coleção), mas discrepam em relação à narrativa construída pela exposição. ${ }^{16}$ Onde Real enxerga uma incapacidade para demonstrar um "senso real de emancipação" dos modelos americanos e europeus, 17 Torrent destaca a evidência empírica de uma liberdade cultural com relação ao "paternalismo inicial que havia significado a arquitetura moderna europeia" e uma leitura não baseada "na suposta dicotomia entre o latino-americano e o internacional, mas na clara integração da região nos parâmetros de qualidade da arquitetura moderna do momento."18

Sabemos que catálogos de arquitetura são produtos bibliográficos onde as imagens costumam ter papel preponderante sobre os textos; de certo modo, não estão distantes do álbum fotográfico. Inclusive, nunca foi alheia à recepção do catálogo Latin American Architecture since 1945 a crítica a uma historiografia de base formalista. Real examinou a reação de Lewis Mumford à exposição, em artigo na imprensa americana (The New Yorker, fevereiro de 1956), em geral crítico com relação à falta de contexto dos edifícios na mostra e à redução ao "puro formalismo, à pura experiência estética". ${ }^{19}$

Não obstante a prioridade da imagem sobre a palavra, o catálogo constitui, também, uma narrativa. $\bigcirc$ objetivo deste texto é interrogar, através do exame de Latin American Architecture since 1945, a condição narrativa própria do catálogo como coleção de imagens de arquitetura, como álbum fotográfico, em suas correlações com os métodos da historiografia e com a formação do conceito de arquitetura moderna latino-americana. Para tomar uma posição com relação à apreciação historiográfica do catálogo, parte de duas premissas: a fotografia, como destacou Barthes, é um certificado de presença; a narrativa, como observou Aumont, se inscreve menos no tempo que na ordem. ${ }^{20}$ 
UM ANTECEDENTE LATINO-AMERICANO NA CURADORIA DE HITCHCOCK

MoMA foi fundado no verão de 1929 por um grupo de patronos das artes, na maioria nova-iorquinos, convencidos de que a cena contemporânea não estava recebendo oportunidades adequadas de apresentação nas instituições existentes. ${ }^{21} \bigcirc$ envolvimento do MoMA com a América Latina aconteceu primeiro na arte e só depois na arquitetura. A $14^{a}$ mostra do museu foi uma exposição dedicada à obra do mexicano Diego Rivera, inaugurada em dezembro de 1931 ; de fato, foi a segunda exposição monográfica organizada pelo MoMA: a primeira, do mesmo ano, fora sobre Matisse. ${ }^{22}$ Peças de arte pré-colombiana provenientes das culturas asteca, maia e inca foram incluídas na exposição "American Sources of Modern Art", em 1933, com o objetivo de enfatizar antes seu significado de referência formal para a arte moderna, que seu valor arqueológico. ${ }^{23}$ Mas a arquitetura latino-americana só entraria no museu bem depois da famosa "Modern Architecture: International Exhibition", dirigida por Philip Johnson em 1932 la qual mais adiante se retornará). Conforme explica Barry Bergdoll, a posterior intensificação do engajamento do museu com a América Latina, que se firma a partir de 1939, sob a presidência de Nelson Rockefeller, reflete tanto os rumos da política externa estadunidense e os interesses comerciais dos Rockefellers, quanto a percepção de que a nova produção latino-americana poderia ser uma aliada na batalha cultural do museu para uma definição do modernismo como atitude contrária aos estilos tradicionais. ${ }^{24} \bigcirc$ sucesso do Pavilhão Brasileiro de Lucio Costa e Oscar Niemeyer na Feira Mundial Mundial de 1939, como contribuição notavelmente moderna a um evento urbanístico cuja visão arquitetônica o MoMA considerava superada e à qual se opunha, forneceu impulso para as futuras apresentações da produção latino-americana no museu. ${ }^{25}$ Em 1940 ○ MoMA exibiu a mostra monográfica "Portinari of Brazil" e a grande exposição "Twenty Centuries of Mexican Art", curada por John McAndrew. ${ }^{26}$ Em 1943, o museu organizou a célebre "Brazil Builds", uma retrospectiva da arquitetura brasileira do período colonial ao período moderno (1652-1942), curada por Philip Goodwin e com fotografias de George Kidder Smith. ${ }^{27}$ No mesmo ano, o museu promoveu a exposição "The Latin-American Collection of the Museum of Modern Art", que apresentava obras de artistas de Argentina, Bolívia, Brasil, Chile, Colômbia, Cuba, Equador, México, Peru e Uruguai. ${ }^{28}$
21. Modern Architecture: International Exhibition (1931c). MoMA Exhs.,15. MoMA Archives, NY.

22. Exposição "Diego Rivera", The Museum of Modern Art, New York, 22 de dezembro de 1931 a 27 de fevereiro de 1932; Exposição "Henri Matisse", 3 de novembro a 6 de dezembro de 1931.

23. Exposição "American Sources of Modern Art", The Museum of Modern Art, New York, 29 de maio a 8 de julho de 1933.

24. Nelson Rockefeller, filho de Abby Aldrich Rockefeller, uma das fundadoras do MoMA, assumiu a posição de Coordenador dos Assuntos Interamericanos do Departamento de Estado dos Estados Unidos em 1940 (BERGDOLL, 2012, p. 48).

25. Bergdoll (2012, p. 48, p. 50).

26. Exposição "Twenty Centuries of Mexican Art", The Museum of Modern Art, New York, 15 de maio a 30 de setembro de 1940; Exposição "Portinari of Brazil", The Museum of Modern Art, New York, 9 de outubro a 17 de novembro de 1940.

27. Exposição "Brazil Builds", The Museum of Modern Art, New York, 13 de janeiro a 28 de fevereiro de 1943.

28. Exposição "The Latin-American Collection of the Museum of Modern Art", The Museum of Modern Art, New York, 31 de março a 6 de junho de 1943. 
29. Exposição "From Le Corbusier to Niemeyer: 1929-1949", The Museum of Modern Art, New York, 15 de fevereiro a 17 de abril de 1949.

30. Philip Johnson havia chefiado o Departamento de Arquitetura do MoMA entre 1932-1934 e volta a fazê-lo entre 1949-1954, quando passou a ser Departamento de Arquitetura e Design.

31. From Le Corbusier to Niemeyer (1949d). The Museum of Modern Art Exhibition Records, 400.4. The Museum of Modern Art Archives, New York; Hitchcock (1948).

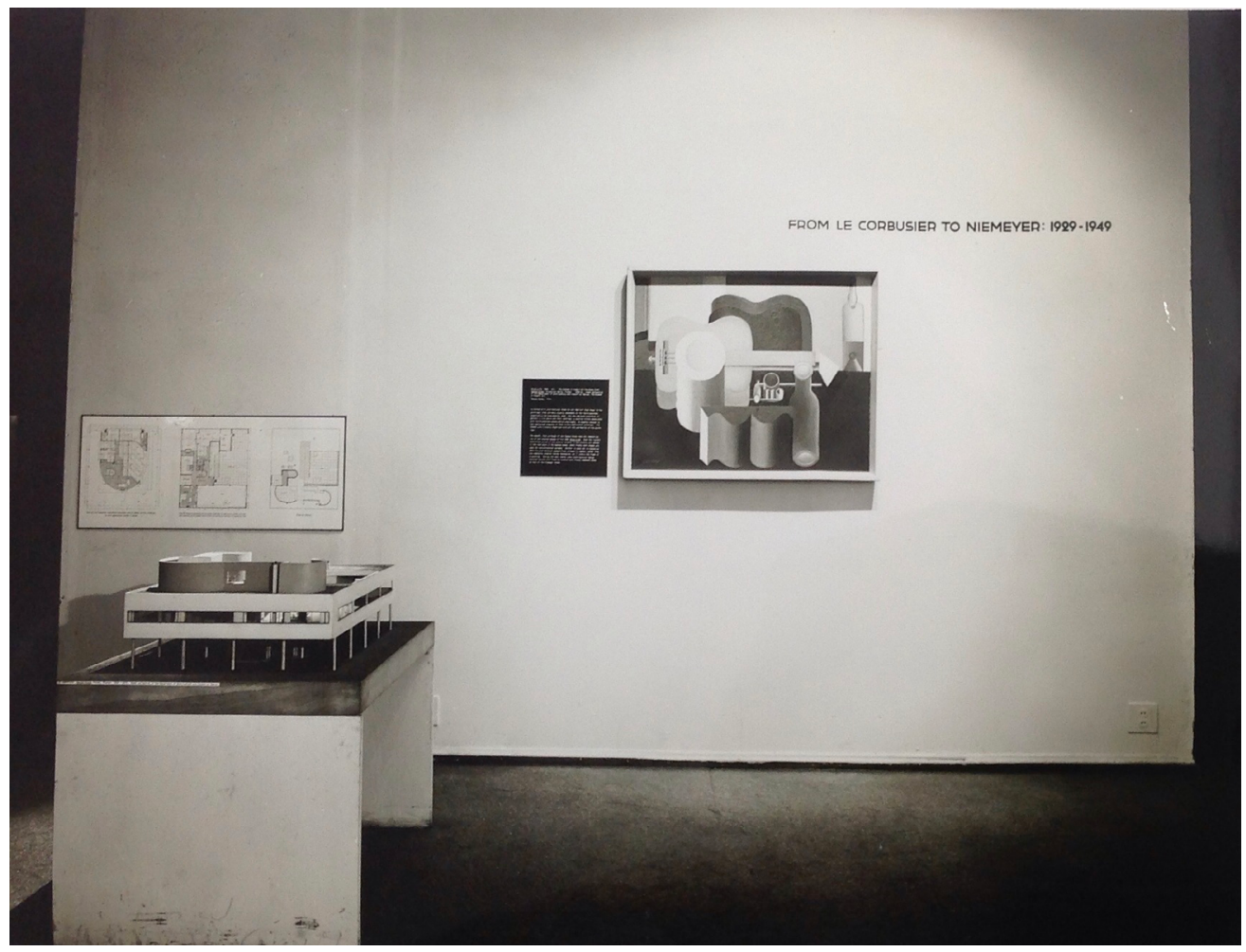

Figura 5 - Exposição "From Le Corbusier to Niemeyer: 1929-1949". The Museum of Modern Art, 15 de fevereiro a 17 de abril de 1949. Fonte: The Museum of Modern Art Exhibition Records, 400.4. Foto: Soichi Sunami.

Assim, a exposição "From Le Corbusier to Niemeyer: 1929-1949", inaugurada no MoMA em fevereiro de 1949, não foi a primeira incursão do museu na produção artística e arquitetônica da América Latina, mas constituiu um elo curatorial precoce entre Hitchcock e a região, que antecede a mostra e o catálogo de 1955 e merece ser examinada (Figura 5). ${ }^{29}$ Dirigida por Philip Johnson, a exposição tinha Hitchcock como consultor e, como assistentes, Peter Blake e Ada Louise Huxtable. ${ }^{30}$ De fato, a ideia básica da exposição era de Hitchcock e boa parte dos textos utilizados procediam de Painting Toward Architecture, livro publicado por Hitchcock em 1948, que versava sobre uma coleção de arte privada - The Miller Company Collection of Abstract Art - formada por Emily e Burton Tremaine enquanto ele era o presidente da Miller Company e ela, a diretora de arte. ${ }^{31}$

"From Le Corbusier to Niemeyer" era uma pequena exposição, ocupando um recinto quadrangular da sede própria do MoMA, projetada por Philip Goodwin e Edward Durrell Stone, para onde o museu havia se mudado dez anos antes. A exposição reunia arte e arquitetura num mesmo contexto explicativo; era sóbria e econômica na instalação, e concisa na escolha das peças, provenientes do acervo 
do MoMA e da Miller Collection. A proposta expositiva opunha dois elementos principais: a Vila Savoye de Le Corbusier, Poissy-sur-Seine, França, 1929-1931, e a Casa Tremaine de Oscar Niemeyer, Santa Bárbara, EUA, 1948-1949, com paisagismo de Roberto Burle Marx. Esta era também uma vila, porém para as praias californianas, encomendada pelo casal Tremaine a Niemeyer. A mostra compreendia as maquetes das duas casas, colocadas sobre dois suportes autônomos, dispostos contra paredes opostas. ${ }^{32}$ Esses modelos físicos eram os únicos elementos tridimensionais e independentes dos planos das paredes apresentados na exposição. As obras que representavam, entre as quais se desdobrava um período de vinte anos, não exerciam apenas o papel de balizas cronológicas, mas eram, sobretudo, os pontos fixos a partir dos quais Hitchcock podia armar uma série de correspondências, tanto entre as arquiteturas de Le Corbusier e Niemeyer, quanto entre essas e os outros elementos pictóricos que compunham a exposição. Sobre as paredes pintadas de um "off-white, ligeiramente amarelo-esverdeado, como a cor de fundo no desenho de Burle-Marx", se dispunham, de um lado, atrás do modelo da Vila Savoye, as plantas da casa e uma natureza morta pintada por Le Corbusier em 1920 e, do lado oposto, atrás do modelo da Casa Tremaine, as cinco pranchas com o projeto de Niemeyer. ${ }^{33}$ O guache colorido de Burle Marx para a Praça Saenz Peña (Tijuca, Rio de Janeiro, 1948) e a obra Relief de Jean Arp (1938-39), um baixo-relevo em madeira, compartilhavam uma terceira parede.

O propósito manifesto da exposição era "mostrar a influência da obra do pioneiro arquiteto suíço, Le Corbusier, naquela do importante arquiteto brasileiro da geração mais jovem, Oscar Niemeyer". ${ }^{34}$ Nesse momento, já se passavam vinte anos da primeira vinda de Le Corbusier ao Brasil, em 1929, e treze da sua segunda visita, em 1936, por recomendação de Lucio Costa, em razão da construção do Ministério de Educação e Saúde no Rio de Janeiro, quando Le Corbusier entrou em contato direto com a equipe de jovens arquitetos brasileiros encarregados do projeto, entre os quais figurava Niemeyer. ${ }^{35}$ Como Lúcio Costa escreveria em carta a Le Corbusier anos depois, essa foi a ocasião em que "as sementes generosas" espalhadas pelo mestre suíço em solo brasileiro revelaram o até então "insuspeitado" talento excepcional de Niemeyer. ${ }^{36}$ Dois anos antes da exposição, Le Corbusier e Niemeyer haviam estado novamente reunidos, dessa vez em Nova York, como parte do comitê de especialistas formado para estudar o projeto da sede da $\mathrm{ONU}$, finalmente realizado segundo o esquema 23-32, que combinava as propostas de ambos. ${ }^{37}$

Embora o ponto de partida da exposição sugerisse uma relação de descendência direta, os nexos propostos pela montagem indicavam uma
32. From Le Corbusier to Niemeyer (1949c). MoMA Exhs., 400.4. MoMA Archives, NY.

33. From Le Corbusier to Niemeyer (1949b). MoMA Exhs., 400.4. MoMA Archives, NY.

34. From Le Corbusier to Niemeyer (1949d). MoMA Exhs., 400.4. MoMA Archives, NY.

35. Equipe brasileira: Lúcio Costa, Oscar Niemeyer, Affonso Eduardo Reidy, Jorge Moreira, Carlos Leão, Ernani Vasconcelos. Sobre as visitas de Le Corbusier ver: Santos, Pereira, Pereira e Silva (1987).

36. Santos, Pereira, Pereira e Silva, op. cit., p. 193-194.

37. A equipe completa de consultores, liderada por Wallace K. Harrison e Max Abramovitz, incluía: G. A. Soilleux (Austrália); Gaston Brunfaut (Bélgica); Oscar Niemeyer (Brasil); Ernest Cormier (Canadá); Ssu-Ch'eng Liang (China); Le Corbusier (França); Sven Markelius (Suécia); N. D. Bassov (URSS); Howard Robertson (Reino Unido); Julio Vilamajó (Uruguai). Ver: Papadaki (1950); Hitchcock e Drexler (1952); Niemeyer (2005). 
38. From Le Corbusier to Niemeyer (1949a). MoMA Exhs., 400.4. MoMA Archives, NY.

39. Id. conversação plural, a partir das correspondências visuais entre as tradições da arte e da arquitetura. Como demonstração sintética do argumento crítico e historiográfico de Hitchcock em Painting Toward Architecture, no seu conjunto, a exposição discutia a possibilidade de causalidades unívocas e derivações diretas na arte. "Os processos de fertilização cruzada pelos quais as influências criativas são transmitidas nas artes permanecem um mistério, apesar de tudo o que está escrito sobre eles", escreve Hitchcock. ${ }^{38}$ Assim mesmo, embora deixe claro que "as formas arquitetônicas de Le Corbusier não 'derivam' daquelas em suas pinturas", Hitchcock considera que "o estudo dos modelos, pinturas e desenhos desta exposição pode ajudar a sugerir como a arquitetura contemporânea atingiu sua forma visual característica". ${ }^{39}$

Comparada à posterior "Latin American since 1945", tratava-se de um evento muito diferente, centrado sobre alguns poucos objetos e sem pretensão de apresentar a arquitetura de um país, muito menos de um continente. Guardava uma relação diversa com o texto. A exposição não circulou, e não originou um catálogo; antes, se utilizou de uma obra existente, o livro Painting Toward Architecture já publicado por Hitchcock. Mas tanto o método quanto a tese por trás dessa pequena exposição podem servir para introduzir a visão de Hitchcock como historiador e curador, e iluminar o seu ponto de vista no catálogo "Latin American Architecture since 1945". A relação visual que se pode estabelecer entre esses objetos, entre a geometria cartesiana e as formas biomórficas, é o verdadeiro motivo da exposição, vinculada a uma tradição formalista, que opera através de evidências visuais. Ao mesmo tempo, são os ditos processos de fertilização cruzada entre as formas, e não a paternidade eventual, que caracterizam a contribuição ao desenvolvimento dos idiomas modernos, os vetores de desenvolvimento de uma tradição artística e arquitetônica.

\section{A EXPOSIÇÃO "LATIN AMERICAN ARCHITECTURE SINCE 1945"}

A exposição "Latin American Architecture since 1945" foi aberta ao público em novembro de 1955. Segundo o comunicado do museu à imprensa, 49 edifícios, de complexos universitários a casas individuais, haviam sido escolhidos entre a "produção recente de onze países latino-americanos" por Henry-Russell Hitchcock, o "conhecido historiador da arquitetura moderna", e "dramaticamente instalados" por Arthur Drexler, curador do Departamento de Arquitetura e Design (Figuras 6 e 7): 
Grandes murais fotográficos, plantas, diapositivos coloridos tridimensionais em visores individuais, são usados para ilustrar o notável progresso recente dos arquitetos latino-americanos, cujo trabalho, diz Mr. Hitchcock, atualmente ultrapassa os edifícios europeus recentes e iguala em vitalidade e interesse a arquitetura moderna neste país. ${ }^{40}$

Da parte de Hitchcock, a exposição era o resultado de um trabalho de campo. Em 1954, o Departamento Internacional do MoMA, dirigido por Porter McCray, havia encarregado o historiador e a fotógrafa Rosalie Thorn McKenna de coletar material para montar uma exposição sobre o desenvolvimento da arquitetura moderna na América Latina na última década. Durante seis semanas, Hitchcock e McKenna visitaram Argentina, Brasil, Chile, Colômbia, Cuba, México, Panamá, Peru, Uruguai, Venezuela e o protetorado Porto Rico.

Conforme destacou Patricio del Real, a intenção do museu era produzir um "Built in Latin America", na linha da Exposição "Built in the USA: Postwar Architecture", apresentada no inverno de 1953.41 "Built in the USA", cujo catálogo foi também preparado por Hitchcock e Drexler, era a segunda mostra realizada pelo MoMA sobre arquitetura moderna estadunidense. ${ }^{42}$ A primeira havia sido "Built in the USA, 1932-1944", produzida durante a segunda guerra, com catálogo de Elizabeth Mock. ${ }^{43}$

O catálogo Latin American Architecture since 1945, assinado por Hitchcock e prefaciado por Drexler, foi lançado em conjunto com a mostra. A exposição deixou o MoMA em fevereiro de 1956. Viajou pelos Estados Unidos, México, Venezuela e Cuba entre 1957 e 1959. Depois disso foi desmontada, e suas peças dispersadas entre os respectivos acervos a que pertenciam. ${ }^{44} \bigcirc$ catálogo é até hoje consultável.

trabalho do historiador pode recuperar as condições e o cenário de uma exposição passada, como fez Patricio del Real com a exposição "Latin American Architecture since 1945", oferecendo uma rica descrição da instalação de Drexler em 1955. ${ }^{45}$ A exposição dispunha de um espaço unitário, cuja geometria original basicamente correspondia a um salão quadrangular, flanqueado por duas alas menores, alinhadas pela face oposta ao ingresso único (coincidente com uma delas). ${ }^{46}$ Entre outros arranjos possíveis - por exemplo, três recintos constituindo uma sequência vestíbulo, grande salão, pequena sala - , a instalação configurava dois ambientes interligados. Através de recursos arquitetônicos precisos, o esquema aproveitava as variações de geometria e profundidade da sala para demarcar dois recintos de características distintas. $\bigcirc$ primeiro deles era definido pela continuidade de um forro rebaixado, que penetrava a sala na direção de sua maior profundidade. Composto de
40. Latin American Architecture since 1945 Press release. November 23, (1955a, Press Preview: Tuesday, November 22. The Museum of Modern Art Exhibition Records, 590.2. The Museum of Modern Art Archives, New York. tradução nossa).

41. Real (2012, p. 308, p. 325-333).

42. Hitchcock e Drexler, op. cit.

43. Mock (1944).

44. Depois de 1959, uma versão compacta em painel continuou viajando pelos Estados Unidos até janeiro de 1961 (Real, 2012, p. 303).

45. Como explica Patricio del Real, Hitchcock viajou para a Inglaterra em junho de 1955, de modo que a exposição "Latin American Architecture since 1945 foi composta e instalada por Drexler, com o auxílio de Mildred "Connie" Constantine, Curadora Associada" (Real, 2012, p. 324-325).

46. Latin American Architecture since 1945 ([1955b?]). Plano da exposição. MoMA Exhs., 590.5. MoMA Archives, NY. 
placas translúcidas com iluminação embutida, o forro baixo insinuava um primeiro espaço retangular, alongado, do tipo galeria, enfatizado pela disposição, em ambos os lados, de grandes painéis fotográficos estendendo-se do piso à linha do forro. $O$ segundo recinto, acessível através dessa galeria, cobrava unidade por meio da cortiça escura usada para revestir as superfícies expositivas, três paredes onde se encaixavam painéis de tamanhos variáveis, sob a uniformidade de um teto escuro e alto. Entre esses ambientes, numa linha virtual paralela à galeria, estavam dispostos três grupos de unidades individuais para visualização de slides.

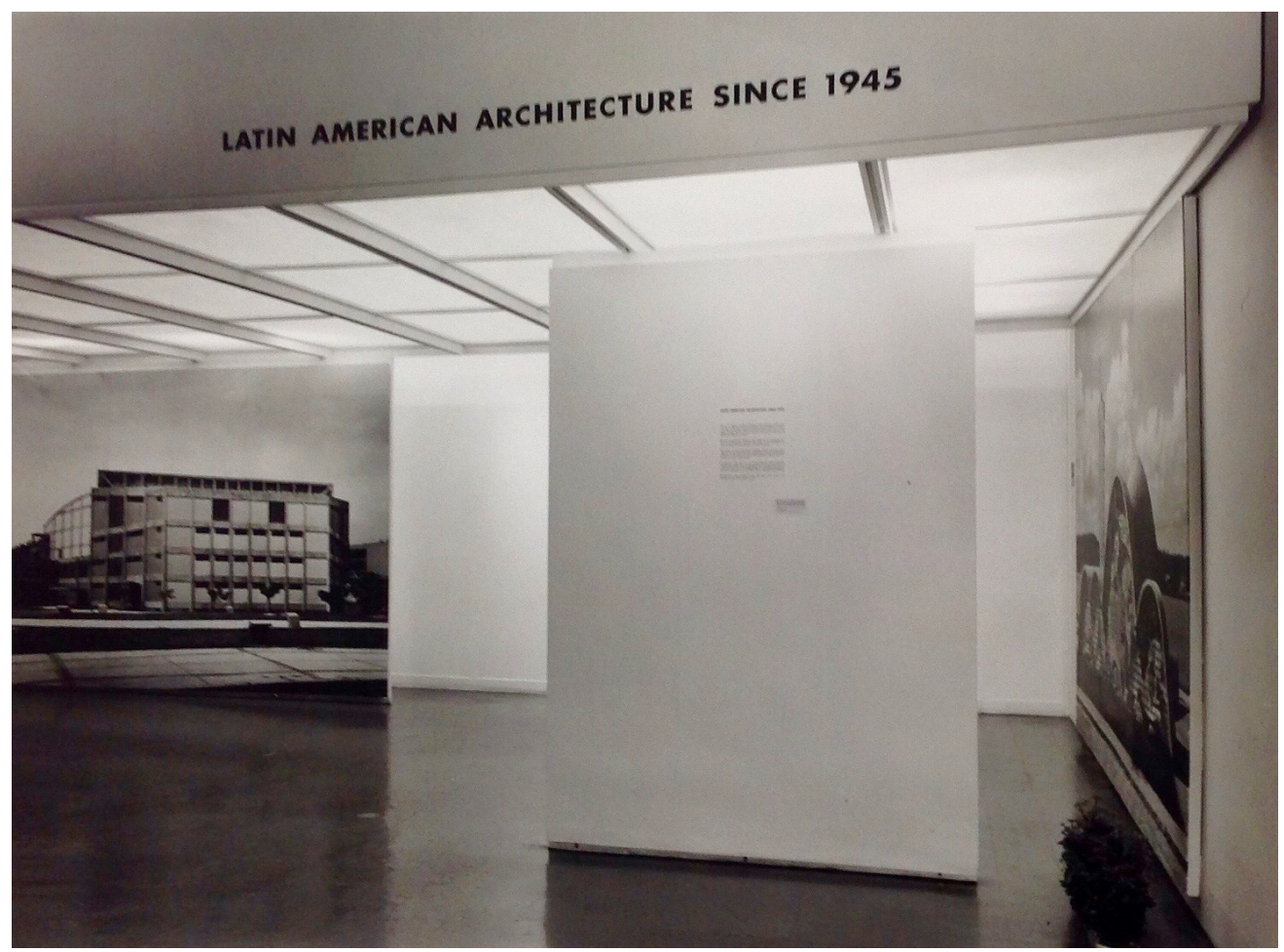

Figura 6 - Exposição "Latin American Architecture since 1945". The Museum of Modern Art, 23 de novembro de 1955 a 19 de fevereiro de 1956. Fonte: The Museum of Modern Art Exhibition Records, 590.2. Foto: Ben Schnall. 


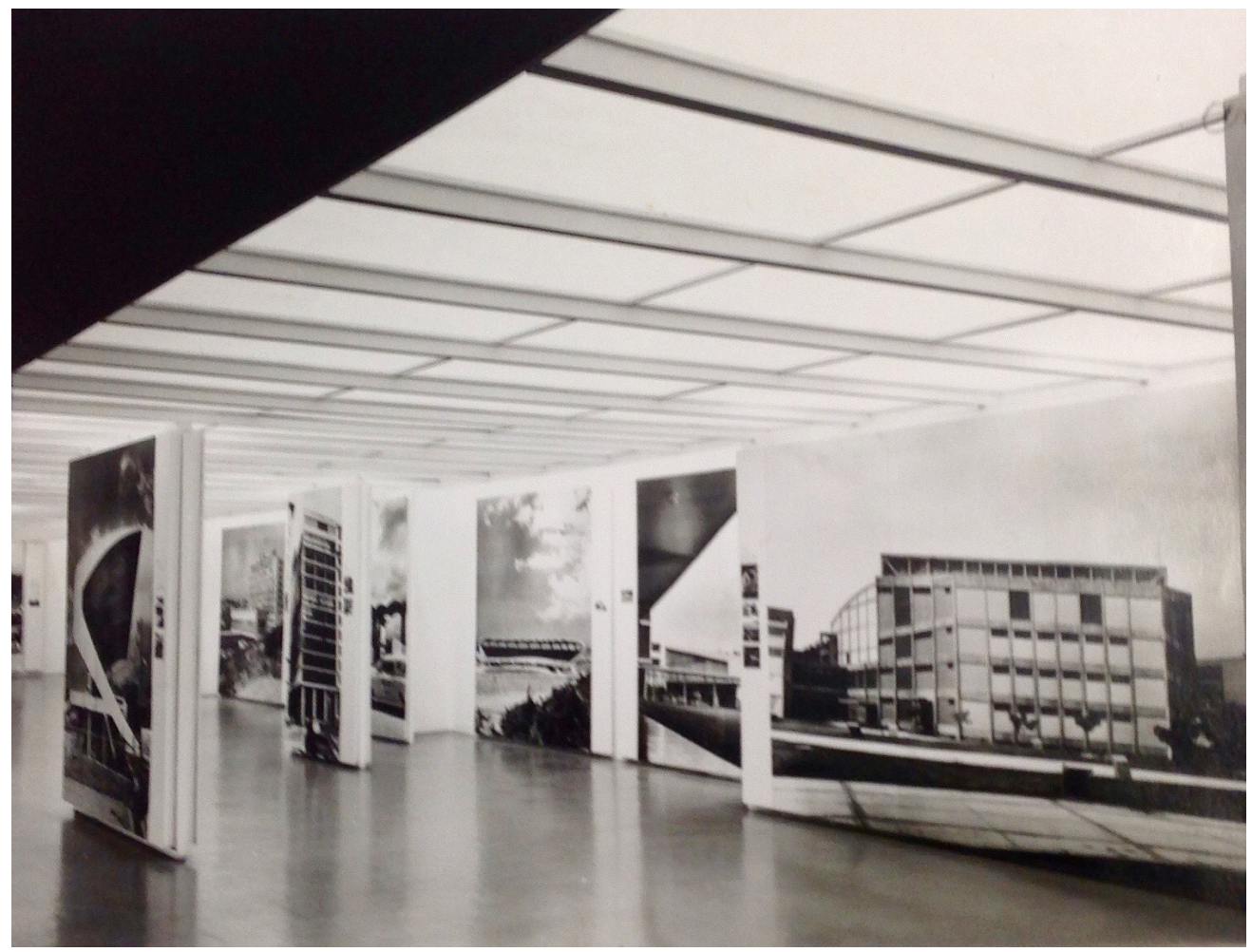

47. Real (2012, p. 329, p. 348).

48. Id., p. 352.

49. Ibid., p. 353.

Figura 7 - Exposição "Latin American Architecture since 1945". The Museum of Modern Art, 23 de novembro de 1955 a 19 de fevereiro de 1956. Fonte: The Museum of Modern Art Exhibition Records, 590.2. Foto: Ben Schnall.

Real destacou certas complementaridades como acertos do arranjo de Drexler: a teatralidade da contraposição entre o "corredor luminoso", com seus vastos painéis, e a sala escura de cortiça, que combinava grandes imagens a outras pequenas, que demandavam o movimento de aproximação por parte do visitante; a dialética entre as fotografias em branco e preto e os slides coloridos, que mostravam a policromia dos edifícios. ${ }^{47}$ Mas, segundo adverte, essas qualidades, que dependiam da experiência da exposição, estavam de certo modo perdidas para o catálogo, não apenas pela impressão em branco e preto, mas também pela necessária fixidez do catálogo. A exposição sugeria uma série de relações entre as obras, como "argumentos visuais" potencialmente abertos, dependentes da capacidade do visitante para reconhecê-los: "o que na exposição era alusão formal ou visual" - argumenta - "transformou-se no contexto do livro num argumento textual fechado". ${ }^{48}$

A ideia de que o catálogo "congelou uma interpretação", avançada por Real, interessa à questão aqui colocada. ${ }^{49}$ Este texto buscará discutir precisamente a "fixidez" do catálogo, como fato inerente à sua condição narrativa. $\bigcirc$ catálogo 
50. Barthes, op. cit., p. 87.

51. Ibid., p. 126.

52. Ibid., p. 65

53. "Modern Architecture: International Exhibition", The Museum of Modern Art, New York, 10 de fevereiro a 23 de março de 1932. é uma coleção no sentido restrito do termo. Latin American Architecture since 1945 refere-se a uma exposição que desejou inserir no ambiente do museu determinadas obras de arquitetura; precisou separá-las, para tanto, do conjunto geral dos edifícios. É a organização posterior desses edifícios numa ordem secundária (seja a ordem da exposição, ou a ordem do catálogo) que permite enxergá-los como coleção: um conjunto sistematizado de objetos legitimados como relevantes por alguma instância disciplinar ou social.

No caso do catálogo de arquitetura, esse processo é em geral dependente da imagem fotográfica. A "referência", segundo Barthes, é a ordem fundadora da fotografia; ela aponta "o que esteve lá" e cria a "dupla posição conjunta, de realidade e de passado". ${ }^{50}$ Ao contrário de outros comentaristas da imagem fotográfica, Barthes afasta-se das posições que se fixam na relatividade semântica da fotografia (segundo as quais não existe "real") e na ideia de imagem como simulacro, fabricação. Para Barthes, toda fotografia é um certificado de presença. Diante dela, o observador reconhece a ausência do objeto, mas "também, simultaneamente e na mesma medida, que esse objeto existiu realmente e esteve lá", onde ele o vê..$^{51}$ E quando Barthes compara a fotografia, imagem imóvel, com o cinema, imagem em movimento, ele explica que a diferença não está apenas no fato de as personagens ou coisas que a fotografia representa não se mexerem, mas sim que elas "não saem de lá: estão anestesiadas e fixadas, como se fossem borboletas" em uma coleção. ${ }^{52}$

\section{ENTRE DOIS CATÁLOGOS: 1932-1955}

Latin American Architecture since 1955 não era o primeiro catálogo de arquitetura moderna organizado por Hitchcock, por encargo do museu. Próximo no tempo ao Built in the USA, feito em coautoria com Drexler e publicado em 1953, - catálogo latino-americano era três décadas posterior às duas publicações decorrentes da famosa "Modern Architecture: International Exhibition", dirigida por Philip Johnson em 1932, à frente do Departamento de Arquitetura do museu. ${ }^{53}$

Hitchcock participou da publicação do catálogo que acompanhava a exposição, sob o título Modern Architecture: International Exhibition, com textos de Alfred Barr, então diretor do MoMA, Philip Johnson e Lewis Mumford (Figura 8). E com Johnson, foi autor do célebre The International Style since 1922, também editado em 1932 e desde então considerado como uma espécie de atestado de amadurecimento e abrangência da nova arquitetura, institucionalmente sancionada 
pelo museu como um movimento de caráter internacional. Conforme a declaração de Alfred Barr sobre a exposição de 1932:

Nunca neste país ou no exterior foi realizada uma Exposição Internacional desta natureza. Obviamente, é de longe a melhor maneira de efetivamente apresentar ao público cada aspecto do novo movimento. ${ }^{54}$

Na verdade, a frutífera temporada das exposições internacionais de arquitetura moderna já havia sido inaugurada pouco tempo antes pelos europeus - e com edifícios reais - com o antecedente ilustre de "Weissenhofsiedlung", a exposição sobre vivenda moderna de Stuttgart, promovida pela Deutscher Werkbund em 1927, cujas imagens, aliás, entraram na exposição do MoMA em 1932. Em Stuttgart não havia americanos, todos os participantes vinham da Europa Central. ${ }^{55} \mathrm{Na}$ ordem fixada pela exposição de 1932, o "novo movimento" já tinha suas estrelas principais e, nessa constelação, os Estados Unidos estavam bem representados. $\bigcirc$ material de divulgação se encarregava de destacar que era "significativo que muitos dos elementos do Estilo Internacional tiveram sua origem na América, no trabalho surpreendente e revolucionário de Frank Lloyd Wright". $56 \mathrm{~A}$ obra de um grupo de proeminentes arquitetos atuantes nos Estados Unidos - que, além de Wright, incluía Raymond Hood, Howe \& Lescaze (Nova York), os irmãos Bowman (Chicago) e o austríaco Richard Neutra, estabelecido em Los Angeles - era detalhadamente apresentada, inclusive com maquetes especialmente confeccionadas para a mostra (Figura 9). Idêntico tratamento era dispensado à obra de quatro arquitetos europeus: Le Corbusier, trabalhando em Paris, Mies van der Rohe e Walter Gropius, na Alemanha, e J. J. P. Oud na Holanda. Além disso, complementavam a exposição, inseridos na categoria "Extensão da arquitetura moderna", outros arquitetos modernos provenientes de Estados Unidos, Finlândia, Suécia, Alemanha, Holanda, França, Tchecoslováquia, Inglaterra, Itália, Suíça, Bélgica, Espanha, Áustria, Rússia e Japão, cujas obras eram documentadas por fotografias. A quantidade de obras por país era variável. Espanha, Itália, Áustria e Bélgica compareciam com um único edifício, embora o catálogo cite outros arquitetos; também da Finlândia, havia uma única obra, de Alvar Aalto. No conjunto, Alemanha e Estados Unidos estavam quantitativamente melhor representados.
54. Modern Architecture: International Exhibition (1931c, tradução nossa).

55. Mies van der Rohe (diretor da exposição), Walter Gropius, Peter Behrens, Adolf Schneck, Bruno e Max Taut, Ludwig Hilberseimer, Hans Poelzig, Adolf Rading, Hans Scharoun e Richard Döcker, da Alemanha; Le Corbusier e Pierre Jeanneret, representando a França; J. J. P. Oud e Mart Stam, pela Holanda; Victor Bourgeois pela Bélgica; e Josef Frank pela Áustria.

56. Modern Architecture: International Exhibition Press release. January 24, (1931b, MoMA Exhs., 15. MoMA Archives, NY. tradução nossa). 


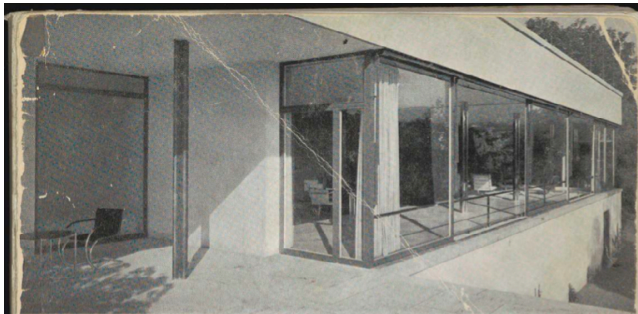

\section{MODERN ARCHITECTURE}

IN TERNATIONAL EXHIBITION

\section{MODERN ARCHITECTURE}

Archive
HoHA
15

NEW YORK FEB, 10 TO MARCH 23,1932

MUSEUM OF MODERN ART

MUSEUM OF MODERN ART
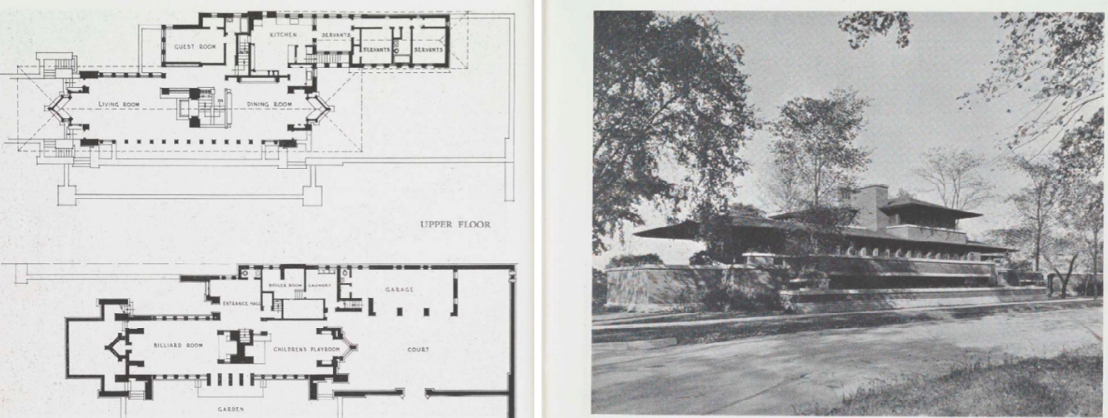

Figuras 8 e 9 - Capa e páginas 50 e 51 do Modern Architecture: International Exhibition (1932).

Embora não se tratasse de construir um bairro real de vivendas modernas, como foi o caso no antecedente europeu promovido pela Werkbund, as maquetes preparadas para a exposição de 1932 correspondiam, majoritariamente, a 
programas residenciais: a Vila Savoye de Le Corbusier lque retornaria em 1949 em From Le Corbusier to Niemeyerl; a Tugendhat de Mies; a casa em Mesa, Denver, de Frank Lloyd Wright; a casa de Oud na Carolina do Norte; uma torre de apartamentos num subúrbio nova-iorquino, de Raymond Hood; o projeto para Chrystie-Forsyth, uma urbanização residencial de Howe \& Lescaze; os Apartamentos Lux, em Illinois, dos irmãos Brothers. As exceções eram a Bauhaus de Gropius em Dessau e o projeto escolar de Neutra para Rush City Reformed, sua cidade ideal de 1926-1927.57 Mesmo que por meio de uma coleção de maquetes, e não de seus referentes construídos, a exposição pretendia sugerir ao público americano uma demonstração equivalente à europeia de uma relação possível entre a "nova arquitetura", como estilo, e a modernização e o melhoramento das condições materiais de vida da população, em seus modos de habitar. Um comunicado do museu à imprensa descreve assim essas "casas do futuro":

Por mais incomuns que possam parecer, com seus telhados planos, sua falta de ornamentação e suas paredes de vidro, elas são essencialmente práticas. Definitivamente, são projetadas para uma boa vida, em uma sociedade ordeira. Elas levam em consideração o conforto e a saúde de seus ocupantes. Elas fazem parte da presente era mecânica [...]. ${ }^{58}$

No catálogo Modern Architecture: International Exhibition, a narrativa é conduzida pela biografia profissional dos personagens centrais. A estrutura do catálogo apresenta sequencialmente o legado de Frank Lloyd Wright, Walter Gropius, Le Corbusier, Oud, Mies, Hood, Howe \& Lescaze, Neutra e irmãos Bowman, comentados separadamente em textos de Hitchcock le de Johnson, no caso de Mies) e ilustrados por imagens das obras. A série "Extensão da arquitetura moderna" é comentada num texto único, seguido da listagem das obras incluídas, organizadas por país e sem ilustrações.

A publicação dos resultados da exposição em The International Style since 1922, por Johnson e Hitchcock, ampliou o número de obras e reforçou ainda mais a representação alemã. Contudo, isso não repercute na estruturação visual do catálogo, que oferece um trato equivalente a todos os exemplares incluídos, na apresentação das imagens. As obras se mostram numa sequência contínua de lâminas, organizadas alfabeticamente pelo nome do autor. A despeito de que, como notou Bergdoll, "continentes inteiros, incluindo a América do Sul, não eram mencionados, muito menos ilustrados", 59 a expressão "Estilo Internacional" - cuja paternidade não é tão clara - parece afirmada com maior decisão do que na outra publicação, Modern Architecture: International Exhibition, em que o
57. Modern Architecture: International Exhibition ([1931a?]). Master Checklist. MoMA Exhs.,15. MoMA Archives, NY.

58. Modern Architecture: International Exhibition ([1931d?]). Press release, s/d. MoMA Exhs., 15. MoMA Archives, NY.

59. Bergdoll, Comas, Liernur e Real, op. cit., p. 18. 
60. Barr (1966, p. 11).

61. Hitchcock e Johnson (1966, p. vii).

62. Barthes, op. cit., p. 14.

63. Hitchcock e Johnson (1966, p. 21, tradução nossa). qualificativo internacional se restringe ao evento expositivo. No prefácio a The International Style since 1922, Barr ressalta que os autores lograram provar, "para além de qualquer dúvida razoável", a existência de um "estilo moderno tão original, tão consistente, tão lógico e amplamente distribuído quanto qualquer outro no passado", e que o "chamaram Estilo Internacional". 60 Anos mais tarde, no seu Painting Towards Architecture de 1948, Hitchcock se refere ao "Mr. Barr's International Style"; e no prólogo escrito para a edição de 1966 de The International Style since 1922, alega que Barr usava "Estilo" com maiúscula no prefácio de 1932, "o que nós no texto não fazíamos". ${ }^{61}$

Contudo, em 1932 o título servia bem para insistir não apenas no alcance do novo movimento, assumido em quinze países por cinquenta estúdios distintos, como também, em igual medida, na relativa homogeneidade da coleção apresentada. A exposição não era o relato de tudo que acontecia na arquitetura, mas o relato de uma escolha. Formar uma coleção significa organizar um recorte; apontar, na "desordem imensa dos objetos" - usando a expressão de Barthes -, aqueles que interessam e excluir outros. ${ }^{62}$ Quando Hitchcock e Johnson foram atrás das borboletas para sua coleção, sabiam de que tipo elas deveriam ser. "O estilo internacional já existe no momento presente", afirmaram, não é algo com que talvez nos deparemos no futuro; "a arquitetura sempre é um conjunto de monumentos reais, não um corpo teórico impreciso" (Figuras 10 e 11 ). ${ }^{63}$

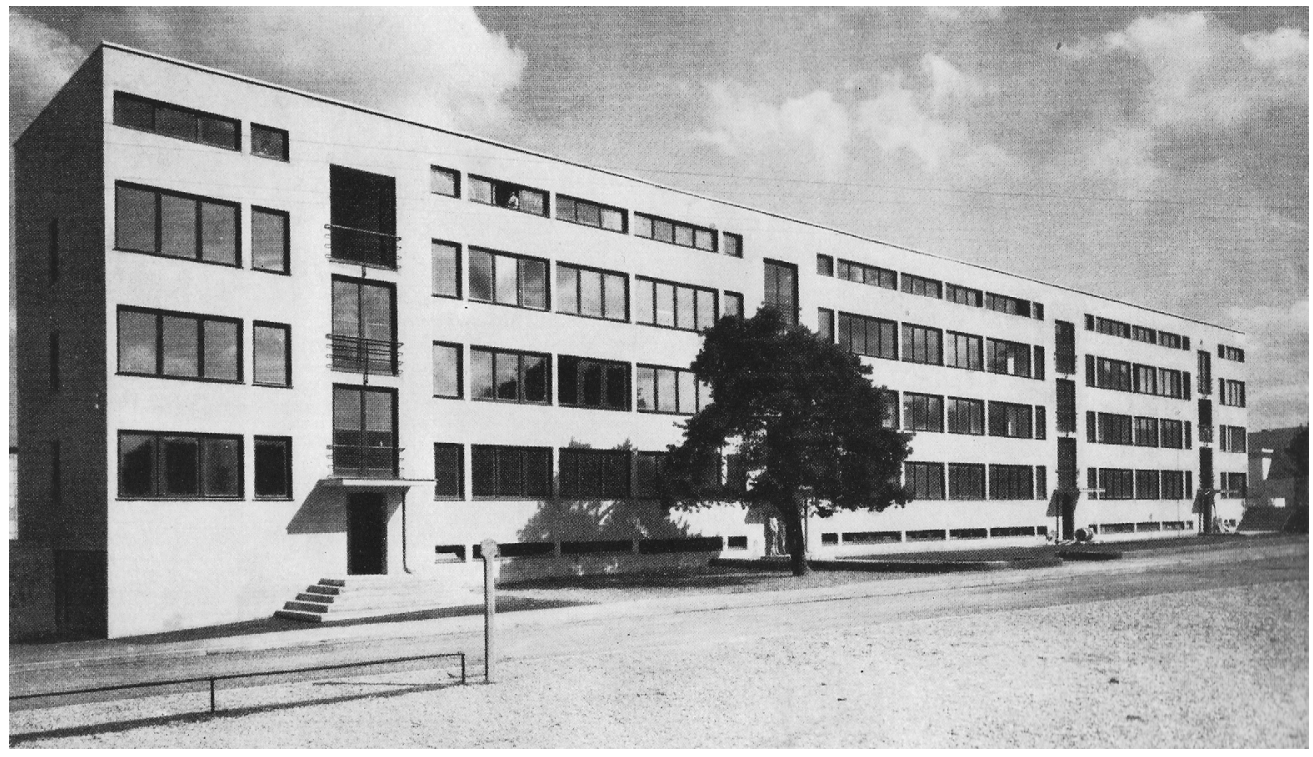

Figura 10 - Mies van der Rohe, Edifício de apartamentos, Weissenhofsiedlung, Stuttgart, 1927. Fonte: Hitchcock e Johnson (1966). 


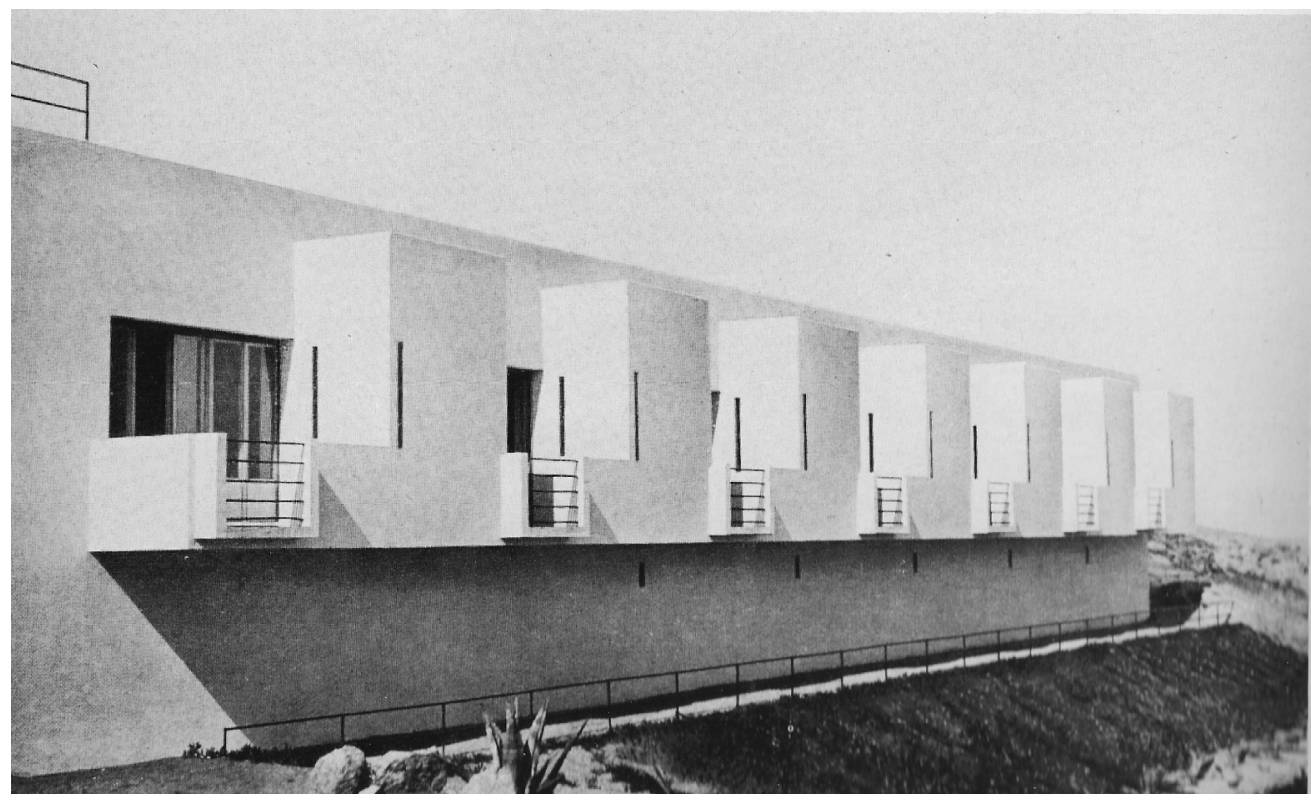

Figura 11 - André Lurçat, Hotel Nord-Sud, Calvi, Córsega, 193 1. Fonte: Hitchcock e Johnson (1966).

No ensaio introdutório, Hitchcock e Johnson não só expuseram as razões dessa escolha, como foram mais além. Em 1932, Hitchcock e Johnson usaram a coleção para estabelecer um cânon estilístico. Em oposição aos múltiplos revivals do século XIX, identificaram um único "sistema disciplinar, suficientemente preciso para fazer do estilo contemporâneo uma realidade, e suficientemente elástico para permitir interpretações individuais e um desenvolvimento geral". Assim, a ideia de estilo, como problema típico do século XIX, era refeita segundo uma nova "disciplina geral de estrutura e de desenho nos termos de sua época": 64

Existe, em primeiro lugar, uma nova concepção da arquitetura como volume mais que como massa. Em segundo lugar, a regularidade substitui a simetria axial como meio fundamental para ordenar o desenho. Estes dois princípios, unidos a um terceiro que proscreve a decoração aplicada arbitrária, são os que caracterizam a produção do estilo internacional. ${ }^{65}$

Porém, a questão é que em 1955, Hitchcock já não parece estar tão convencido da validade deste cânon. Como escreve em Latin American Architecture since 1945: 
66. Hitchcock (1955c, p. 60, tradução nossa)

67. Para um relato completo das sucessivas revisões a que tanto Hitchcock quanto Johnson submetem a noção de estilo internacional ver o prólogo de María Teresa Muñoz à edição espanhola de The International Style: Architecture since 1922 (MUÑOZ, 1984, p. 9-26).

68. Sobre O'Gorman, ver Noelle (2021); sobre Warchavchik, ver Lira (2011).

69. Hitchcock (1942, p. 29, tradução nossa).
[A arquitetura moderna na América Latina] ainda pertence, se não ao "Estilo Internacional", conceito agora de algum modo demasiado estreito para a arquitetura moderna, tal como essa tem se desenvolvido nos últimos trinta anos, à corrente internacional que tem fluído cada vez mais forte e amplamente desde 1920.60

Não seria essa a primeira nem a última ocasião em que Hitchcock e também Johnson revisariam os termos da proposta de 1932, ao longo de suas vidas profissionais. ${ }^{67}$ Efetivamente, de um ponto de vista historiográfico, o reconhecimento da relevância singular da exposição tampouco preveniu as críiticas, que, ao longo do tempo, variaram em grau e natureza. Em geral, se chamou a atenção para os limites da coleção. Por um lado, a própria aceitação da proposta do estilo internacional, tal como enunciada no texto de Hitchcock e Johnson como definição suficiente da arquitetura moderna, em algum momento conduziu à conclusão lógica de que havia exemplares já construídos, e esquecidos, fora de Europa e Estados Unidos, como as casas de Juan O'Gorman para Cecil O'Gorman (1929), Diego Rivera e Frida Kahlo (1931-1932) na Cidade do México, ou as casas de Gregori Warchavchik em São Paulo (1927 e 1930), que sim poderiam ter cabido no cânon de 1932.68

Por outro lado, um outro tipo de crítica inclinou-se a censurar o critério estilístico como categoria suficientemente abrangente para declarar o que era ou não era arquitetura moderna. De fato, já em 1942, no artigo "Some Problems in the Interpretation of Modern Architecture", fica bastante claro que Hitchcock tinha consciência da amplitude do dilema historiográfico:

O primeiro problema que me vem à mente na interpretação da arquitetura moderna é tão básico e tão difícil que dificilmente será resolvido, exceto com o tempo. Refiro-me à questão do que devemos incluir no campo da arquitetura moderna. Por um lado, é conveniente, na ausência de qualquer termo aceito, pensar na arquitetura moderna como uma forma ampla de incluir os edifícios dos últimos 150 anos, desde o colapso da síntese barroca em meados do século XVIII. Por outro lado, muitas vezes é conveniente pensar a arquitetura moderna em um sentido mais restrito, referindo-se especificamente àqueles tipos de arquitetura que nos parecem peculiar e propriamente dos dias atuais. ${ }^{69}$

A posição de Hitchcock em 1955 deve ser examinada em relação ao debate emergente, no segundo pós-guerra, sobre os desenvolvimentos da arquitetura moderna. Em 1948 o próprio MoMA havia organizado o simpósio What is happening to modern architecture? - do qual participaram Hitchcock, Alfred Barr, Lewis Mumford, entre outros -, precisamente a partir de uma pergunta sobre o desenvolvimento da arquitetura moderna, e concluído que essa pergunta permanecia sem solução. A expectativa inicial era mostrar as posturas de dois 
grupos, um identificado com a visão dos promotores do "International Style", nomeadamente, Hitchcock e Barr, e outro que representava a reação ao estilo internacional, defendida pelos partidários ingleses do "New Empirism" e seus colegas americanos da "Bay Region".70 Entretanto, conforme a resenha do simpósio publicada no boletim do museu, a controvérsia logo se traduziu numa discordância que operava num nível mais básico, opondo "aqueles que falavam em termos de estilos" aos que "denunciavam todos os rótulos e 'ismos' como secundários ao problema da produção." 71 Hitchcock e Barr estavam no primeiro grupo. Uma condição de partida, para esse grupo, era a aceitação plena da arquitetura como uma arte, tal como colocado por Barr:

Estamos do lado da arquitetura como uma arte, e não do lado da mera construção, por mais estruturalmente eficiente, comercialmente bem-sucedida, sentimentalmente eficaz, humanisticamente plausível ou internamente agradável que essa construção possa ser. ${ }^{72}$

As observações de Hitchcock no já referido Painting Toward Architecture, contemporâneo ao simpósio, apontavam na mesma direção. Além disso, Hitchcock ainda chamava atenção para o sentido opaco da noção de "funcionalismo" como fundamento crítico:

A arquitetura moderna, como qualquer arquitetura do passado, atende a necessidades funcionais por meio da estrutura material. Para aqueles que são verdadeiros "funcionalistas" em teoria - isto é, aqueles que contentam em restringir-se a uma arquitetura-engenharia este pode parecer um programa suficiente. Mas qualquer arquitetura também existe como um agrupamento visual de elementos materiais. Em relação a esse agrupamento, várias atitudes conscientes são possíveis. Para a atitude estritamente funcional, o efeito visual é sem consequências; se o observador deseja encontrar interesse significativo na arquitetura, ele deve estar suficientemente informado para ser capaz de ler em cada edifício seus objetivos complexos e estimar a eficiência com que estão sendo atendidos. É claro que isso é idêntico à atitude inteligente em relação a vários outros produtos técnicos elaborados, como motores e ferramentas mecânicas. A possibilidade de julgar ou "apreciar" edifícios em termos funcionalistas é restrita, senão apenas a quem os utiliza, pelo menos a quem tenha o incentivo, o tempo e a formação especial para estudar detal hadamente os seus fins. ${ }^{73}$

Contudo, segue argumentando Hitchcock, "são as formas, as configurações e os padrões da arquitetura que todos apreendem em primeiro lugar" e que, por isso, têm também valor de sobrevivência. ${ }^{74}$ Seria esse sentido cultural compartilhado das formas arquitetônicas - e, portanto, também dos estilos arquitetônicos - que constituiria a garantia contra a obsolescência de seu significado:
70. Barr et al. (1948, p. 4).

71. Ibid.

72. Ibid., p. 5, tradução nossa.

73. Hitchcock (1948, p. 14-

15, tradução nossa).

74. Ibid., p. 15. 
75. Ibid., p.16, tradução nossa.

76. Ibid., p.16.

77. Hitchcock (1947, p. 4)

78. Hitchcock (1951, p. 89, tradução nossa).

79. Hitchcock (1951, p. 90 , tradução nossa).
Os grandes monumentos da arquitetura antiga - principalmente, é claro, quando estão em ruínas - estão tecnicamente obsoletos há séculos e até dezenas de séculos, mas culturalmente são menos obsoletos do que grande parte da produção arquitetônica atual. ${ }^{75}$

Assim, na opinião de Hitchcock, a despeito da insistência dos arquitetos do século XX em rejeitar, com maior ou menor veemência, as conotações da palavra "estilo", eles haviam trazido à luz, sem qualquer sombra de dúvida, uma arquitetura nova em suas formas; e, de certo modo, respondido à demanda daqueles arquitetos do século XIX que, recusando os revivalismos, clamavam pela "criação de um novo estilo". 76

Essas duas visões - de um lado, o apreço pela arquitetura como arte e a correspondente afinidade com a noção de estilo como categoria crítica; e, de outro, a tendência funcionalista a restar importância a um debate sobre a forma da arquitetura - também eram subjacentes ao argumento desenvolvido por Hitchcock no artigo "The Architecture of Bureaucracy and the Architecture of Genius", publicado na revista inglesa The Architectural Review em 1947. Numa previsão sobre o futuro da arquitetura moderna, Hitchcock afirmava que o problema fundamental, na segunda metade do século XX, não seria a atualização da arquitetura com relação a condições técnicas e culturais, mas sim a qualidade. $\bigcirc$ artigo sugeria uma divisão essencial da cena arquitetônica em duas frentes: uma que se poderia chamar de "arquitetura burocrática", que correspondia a um produto corporativo, onde a capacidade organizativa para produzir um sistema eficaz prevalece sobre a expressão original; e outra que se poderia chamar "arquitetura de gênio", que implicava uma aposta de conteúdo artístico. Da segunda, a arquitetura de gênio, "muito pouco veremos nos próximos anos", especulava Hitchcock."7

Por último, em 1951, Hitchcock escreve um artigo para a Architectural Record, que foi depois anexado à edição de 1966 de The International Style since 1922. No artigo, faz um balanço dos vinte anos do estilo internacional e afirma que a convergência inicial da nova arquitetura já não justificava a sua consideração atual como o "único padrão adequado para a arquitetura moderna." 78 Em The International Style Twenty Years After, Hitchcock confrontava as definições de vinte anos antes sobre as características do "estilo internacional", tal como formuladas no catálogo da exposição de 1932, e as evidências atuais. Reforçando o que havia colocado em Painting Toward Architecture, afirmava que em geral foi o conceito de "estilo" em si mesmo, em tanto que "implicando restrição ou disciplina atendendo a regras estabelecidas a priori," que teve maiores dificuldades de aceitação por parte dos arquitetos. ${ }^{79}$ Gropius, por exemplo, estaria entre os "mais perturbados pela ideia de que qualquer coisa que pudesse ser chamada estilo, no sentido histórico do termo," tivesse algo que ver com a arquitetura moderna: 
Gropius orgulha-se de que seja difícil distinguir o trabalho de um de seus pupilos de outro - uma dificuldade que ele de fato exagera. [...] Mas o que é esse anonimato que o chefe do Departamento de Arquitetura de Harvard admira no trabalho de seus pupilos, se não um estilo comum? ? $^{80}$

Mas em 1951, os "individualistas" the parecem menos equivocados do que ele e Johnson haviam julgado vinte anos atrás. A arquitetura moderna deveria ser capaz de abrir novamente espaço para um leque de efeitos "tão diversos, se não tão divergentes", quanto a Maison du Peuple de Victor Horta em 1897 e o River Forest Golf Club de Wright em 1898. "Recusar hoje uma liberdade de escolha comparável", argumenta, "somente porque 25 anos atrás o desenvolvimento da arquitetura moderna começou a ser notavelmente convergente, é certamente uma forma de academicismo". ${ }^{81}$

Ao contrário, após 25 anos, a "elasticidade" e a possibilidade de "crescimento geral" do estilo internacional é que deveriam ser valorizadas, a despeito de os princípios enunciados tão firmemente em 1932 the parecerem "muito poucos e muito estreitos." ${ }^{2}$

Hoje eu deveria certamente adicionar articulação da estrutura, provavelmente fazendo esse o terceiro princípio; e eu também omitiria a referência ao ornamento, que é antes uma questão de gosto que de princípio. ${ }^{83}$

A linha de argumentação adotada por Hitchcock em sua autocrítica, acusando de academicismo o modernismo restritivo, demonstra a existência de posições confrontadas. Diante das teses do anonimato como virtude, recusadas por Hitchcock, mas sustentadas por Gropius, podemos pensar nos argumentos de um Max Bill, por exemplo, e nos ataques à arquitetura moderna brasileira que viriam em seguida. ${ }^{84} \mathrm{E}$ podemos pensar que Hitchcock não estava só revisando a sua posição, mas também assumindo uma posição diante do debate sobre os rumos da arquitetura moderna nos anos 1950.

Não era da validade da arquitetura moderna de que Hitchcock já não estava convencido, nem da ideia de estilo como disciplina de desenho, apesar das críticas que a noção sofreu, mas da capacidade do cânon de 1932 para explicar os desenvolvimentos da arquitetura moderna, em sua complexidade e variedade real. Nesse caso, a coleção latino-americana possuía as borboletas exatas para comprovar pelo menos dois pontos: que ainda havia alguma "arquitetura de gênio", o que superava as expectativas pessimistas de Hitchcock em 1947; e a sobrevivência do estilo internacional, mais além do cânon de 1932.
80. Id.

81. Ibid.

82. Hitchcock (1951, p. 91 , tradução nossa).

83. Id.

84. Max Bill... (1953, 1954). Ver sobre o tema: Comas (2013); Cabral (2013). 
85. Hitchcock e Johnson (1966).

86. Myers (1952).

87. Hitchcock (1955c, p. 12).

88. Id., p. 76-77.

89. Cf. Cabral (2020, p. 8788).

\section{A COLEÇÃO DE 1955}

Se as imagens de 1932 confirmavam o cânon, as imagens da coleção latino-americana, embora compartilhando, ainda, daquela mesma disciplina geral de estrutura e desenho, exibem elementos provavelmente antes inadmissíveis. ${ }^{85}$ No catálogo Latin American Architecture since 1955, a coleção é apresentada por um ensaio introdutório escrito por Hitchcock. Neste ensaio, Hitchcock destaca o papel de Brazil Builds, catálogo de Goodwin e Kidder Smith publicado em conjunto com a exposição no MoMA em 1943, como um antecedente fundamental no interesse internacional sobre a arquitetura produzida na América Latina. Desde então, conforme explica, periódicos de circulação internacional, tais como L'Architecture d'Aujourd'hui, The Architectural Review, Domus, Architectural Forum e também a brasileira Habitat, difundiram regularmente a atividade arquitetônica na região. A esses exemplos se poderia agregar o livro de Irving Evan Myers, Mexico's Modern Architecture, publicado em 1952.86 "Particularmente nos últimos cinco anos", escreve Hitchcock, "tornou-se evidente que a vitalidade dessa atividade não estava limitada ao Brasil", tendo em vista que as "Cidades Universitárias de México e Caracas, em particular, têm atraído vasta atenção tanto da imprensa geral quanto da profissional". ${ }^{87}$

A Cidade Universitária do México, que aparece várias vezes no catálogo de 1955, iá não era um conjunto de edifícios onde fosse obedecida a restrição à decoração aplicada, como rezava o cânon de 1932. A lâmina 6 do catálogo Latin American Architecture since 1945 corresponde ao edifício da Biblioteca Central (1951-1953), de Juan O'Gorman, Gustavo Saavedra e Juan Martínez de Velasco. "Embora não seja o maior, nem o mais alto dos edifícios da Cidade Universitária do México, a Biblioteca é certamente o mais original", escreve Hitchcock, pois $\mathrm{O}^{\prime}$ Gorman usou as paredes cegas da torre onde se armazenam os livros, marcadas apenas por pequenas janelas nas escadas, "como um códice ilustrado". Na fotografia (Figura 12), o corpo alto do edifício aparece recoberto pelo gigantesco mosaico figurativo de autoria do próprio $\mathrm{O}^{\prime} G$ Gorman, arquiteto e pintor, faceando um dos principais espaços abertos do campus, e avaliado por Hitchcock como "o exemplo de maior sucesso do uso em larga escala da decoração figural na arquitetura moderna, da qual os mexicanos são especialmente adictos". ${ }^{88}$ Nesse ponto, cabe destacar que Hitchcock está tomando uma posição contrária a boa parte da crítica arquitetônica da época, que havia seguido Max Bill em sua diatribe contra o mural na arquitetura moderna, dirigida a brasileiros e mexicanos. ${ }^{89}$ 
A lâmina 11 do catálogo Latin American Architecture since 1945 corresponde ao Estádio Olímpico (Cidade Universitária do México, 1951-1952), de Augusto Pérez Palacios, Raúl Salinas e Jorge Bravo (Figura 13). Uma planimetria e uma seção esquemática mostram que o estádio é uma construção de forma ovalada, inscrita num anel circular, semienterrada com relação à cota de ingresso. As arquibancadas crescem e se elevam na direção leste-oeste, para se retraírem na direção norte-sul e conformar, assim, o perfil elíptico do estádio. Na página oposta, a fotografia tomada por McKenna está centralizada sobre o acesso principal, abarcando integralmente a face oeste. $\bigcirc$ ponto de vista escolhido por McKenna revela uma fachada regrada pela simetria axial, sublinhada pelo relevo policromático de Diego Rivera sobre o pórtico de acesso, que o próprio Hitchcock descreve como "decoração figurativa". 90 Não se trata apenas de tolerar a simetria e a inclusão do elemento decorativo, mas de tornar evidente a primeira e funcional, o segundo. A despeito de que o edifício pudesse ser inteiramente circulado, o enquadramento fotográfico escolheu retratá-lo precisamente de onde ele se vê simétrico.

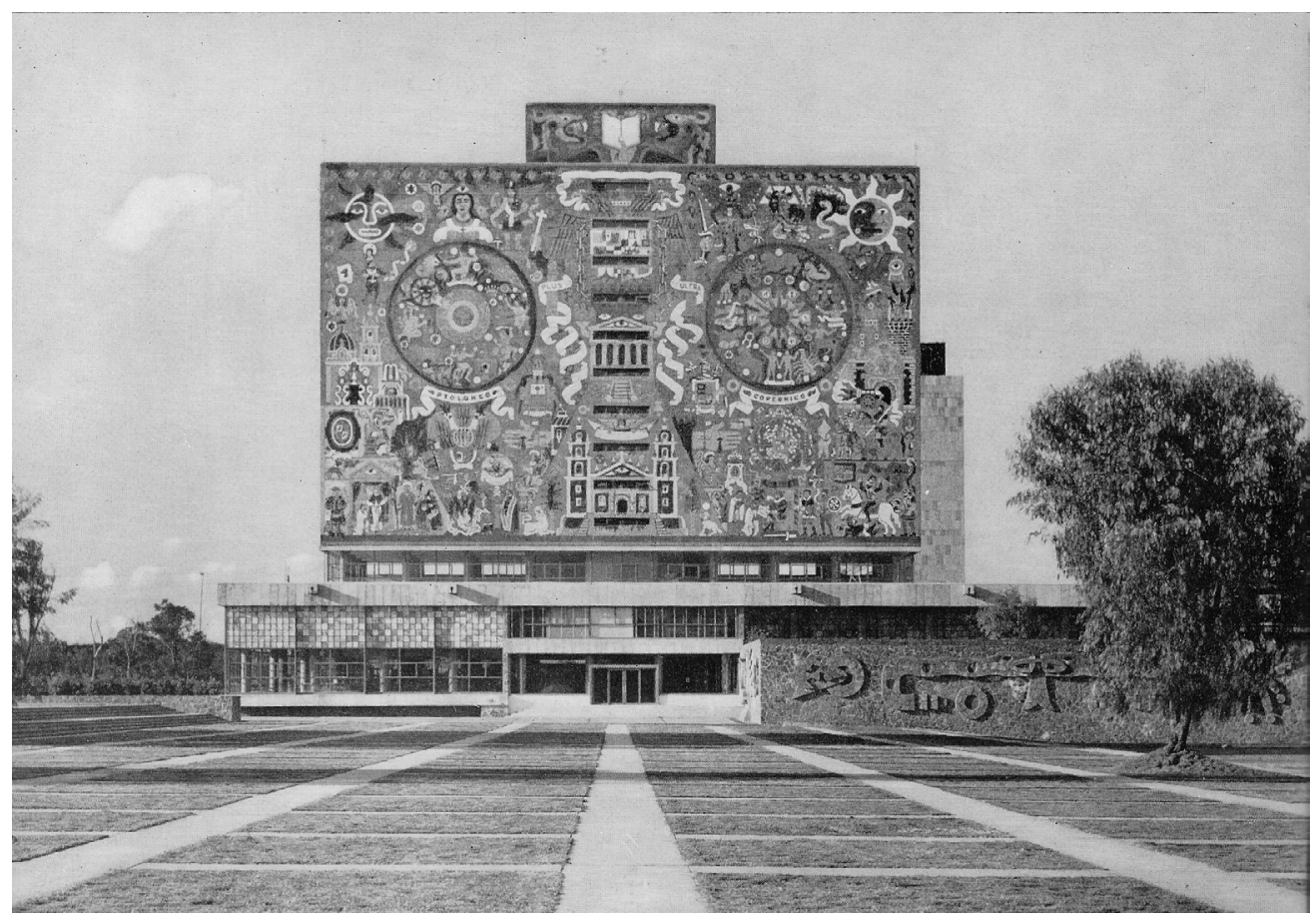

Figura 12 - Biblioteca Central, 1951-1953, Cidade Universitária do México, por Juan O'Gorman, Gustavo Saavedra e Juan Martínez de Velasco. Fonte: Hitchcock (1955c). 
91. Ibid., p. 11, tradução nossa.

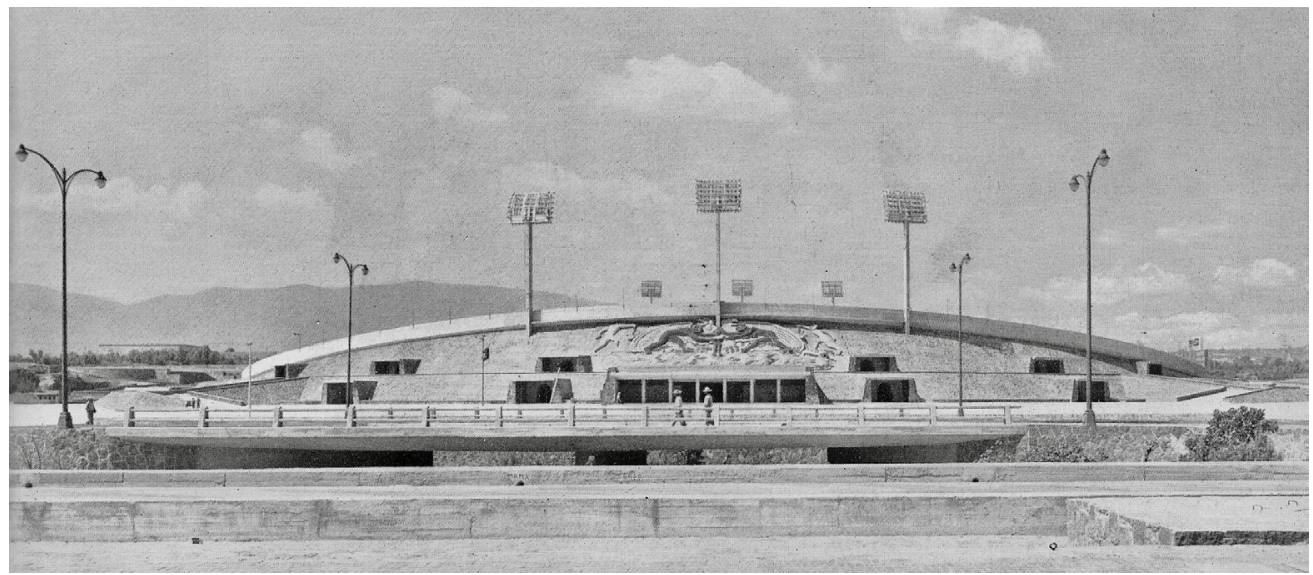

Figura 13 - Estádio Olímpico, 1951-1952, Cidade Universitária do México, por Augusto Pérez Palacios, Raúl Salinas e Jorge Bravo. Fonte: Hitchcock (1955c).

No ensaio, Hitchcock faz referência a obras de arquitetura moderna realizadas na América Latina anteriores a 1945, cuja relevância internacional já estava reconhecida, como o Ministério de Educação e Saúde (1936), de Costa, Niemeyer e equipe e o Aeroporto Santos Dumont (1940), de Marcelo e Milton Roberto, no Rio de Janeiro, ou a Faculdade de Engenharia da Universidade da República em Montevideo, de Julio Vilamajó (1 937). Mas a coleção propriamente apresentada pelo catálogo estava formada por 47 obras realizadas entre 1945 e 1944, envolvendo 38 estúdios de arquitetura. Nem todos esses arquitetos estavam consagrados internacionalmente, como estavam Niemeyer e Costa no Brasil, Carlos Raúl Villanueva na Venezuela, ou Mario Pani no México. Bem como nem todos tiveram encomendas públicas da mesma envergadura entre 1945 e 1955, o que pode explicar certas assimetrias e o fato de que as participações de Argentina e Chile, por exemplo, se limitarem, naquele momento, a obras privadas. Mas a coleção de 1945-1955, no seu conjunto, é comparável em extensão à coleção de 1932 e suficiente para confirmar a relação entre "qualidade e quantidade", um dos aspectos sobre os quais Hitchcock insiste no ensaio introdutório:

Que há alguma conexão entre quantidade e qualidade na arquitetura ninguém pode negar, mesmo que a mecânica dessa relação seja misteriosa. Nem todos os booms de construção produzem momentos de distinção, e a esplêndida Unité d'Habitation de Le Corbusier surgiu na França do pós-guerra onde havia poucas construções novas. Mas na maioria dos países latino-americanos existe, hoje, quantidade e qualidade na arquitetura. ${ }^{91}$ 
Em relação ao paralelo pretendido com a anterior Built in U.S.A., exibida no museu em 1953, Hitchcock sustenta que a coleção latino-americana supera, em interesse e variedade, aquela apresentada na mostra americana, e que a esta se iguala quanto ao nível médio das obras incluídas. ${ }^{92}$ Essa variedade poderia ser em alguma medida reputada à diversidade física, política, social e cultural que a unidade nominal América Latina engloba, cuja heterogeneidade real, como nota Hitchcock, de certo modo encobre. ${ }^{93}$ Mas não exclusivamente. De certo modo, Hitchcock encontrou na variedade dessa coleção tanto a excepcional arquitetura de gênio, quanto a arquitetura anônima de boa qualidade; e tanto a adesão estilística à arquitetura moderna, quanto a independência com relação aos mestres americanos e europeus. Na sua opinião, se "nem o século XIX nem os primeiros anos do século XX pareciam haver produzido importantes desenvolvimentos autóctones" na arquitetura da América Latina, ${ }^{94}$ a situação no pós-guerra era inteiramente diversa e não sugeria nenhum tipo de "desdobramento provinciano" da América do Norte ou da Europa:

\footnotetext{
Mesmo as influências de grandes mestres, Wright e Gropius e Mies, raramente são muito perceptíveis; o que é ainda mais surpreendente, pois nenhum arquiteto latino-americano ainda, exceto Niemeyer, estabeleceu um estilo tão nitidamente pessoal que sua influência sobre os colegas mereça ser comentada. Em certo sentido, existe na América Latina atual - pelo menos fora do Brasil e do México - algo que se aproxima do ideal de Gropius de uma arquitetura anônima impessoal. Mesmo as características nacionais são frequentemente melhor explicadas por diferentes condições climáticas ou diferentes materiais e métodos de construção do que por correntes culturais mais profundas..$^{95}$
}

Uma vez assumidas as limitações do cânon de 1932 para explicar os rumos do estilo internacional, não parece haver intenção, de parte de Hitchcock, de encontrar-lhe um substituto latino. Entretanto, o ensaio explicita algumas características gerais, comuns aos componentes da coleção latino-americana, antes de elaborar alguns comentários mais específicos sobre a situação em cada país. Uma dessas características tem relação com o efeito do clima sobre a arquitetura, mesmo levando-se em conta a extensão do território mapeado e as diferentes latitudes percorridas. Salientando que nem tudo é trópico, Hitchcock valoriza, assim como havia feito Goodwin em Brazil Builds, os mecanismos arquitetônicos de controle da incidência solar, fossem eles herdados da construção tradicional, fossem inventados pelos arquitetos modernos (Figura 14). ${ }^{96}$
92. Ibid., p. 13.

93. "À primeira vista, a América Latina, pelo próprio nome que aplicamos a ela, pode ser considerada mais uniforme etnicamente e, portanto, psicologicamente, do que de fato é o caso." Ibid., p. 27, tradução nossa.

94. Ibid., p. 17, tradução nossa.

95. Ibid., p. 21 , tradução nossa.

96. Ibid., p. 26. 


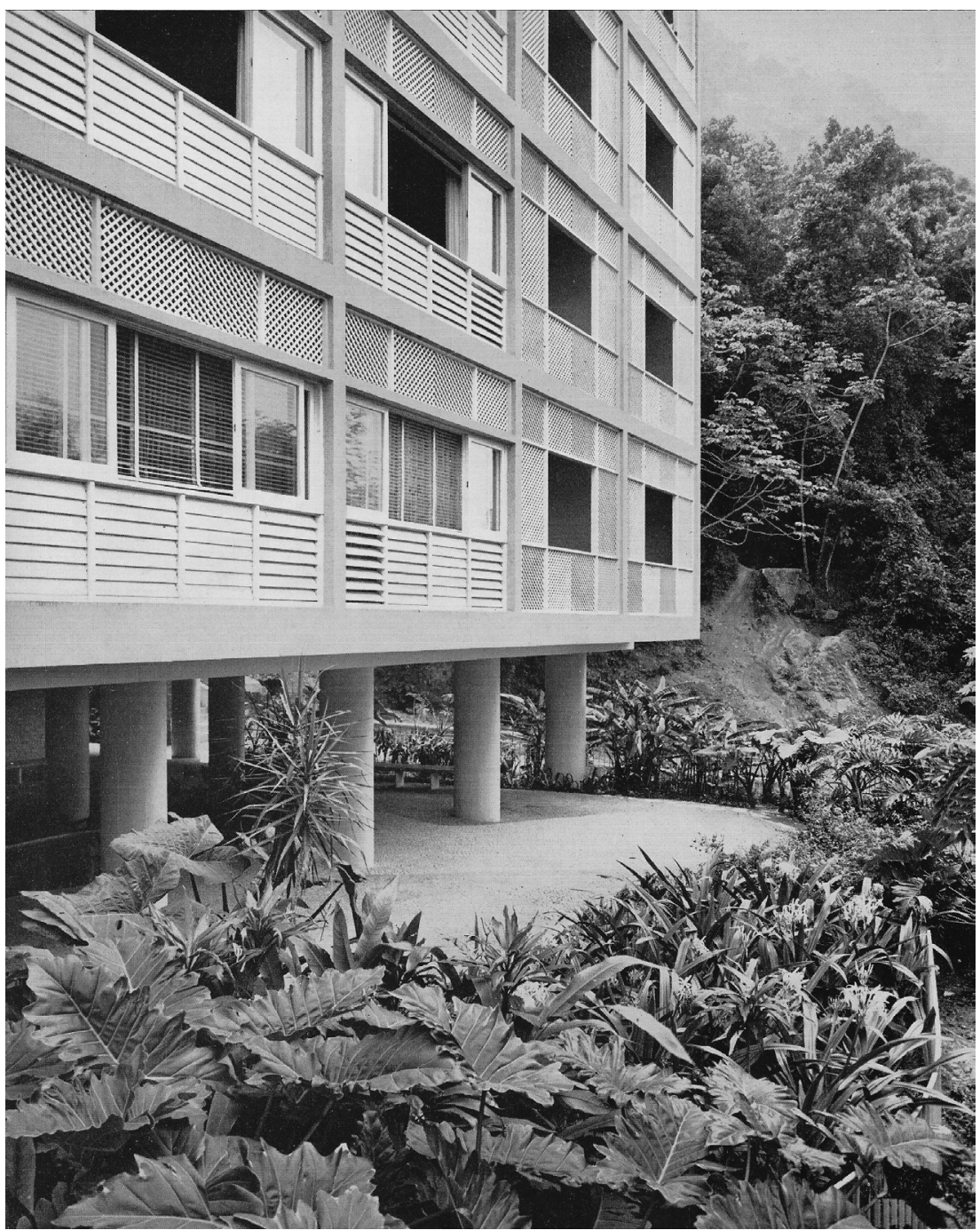

Figura 14 - Jorge Machado Moreira. Edifício Antonio Ceppas, Rio de Janeiro, 1952. Fonte: Hitchcock (1955c). Foto: Michel Aertsens.

Outro aspecto mencionado é uma sensível homogeneidade no que se refere aos materiais e métodos de construção. Ao contrário do cenário estadunidense, o concreto armado e a alvenaria de tijolos predominavam largamente sobre a construção em ferro e madeira. Empregado em geral segundo a maneira corrente, o concreto armado também encorajou os arquitetos na exploração de novas alternativas técnicas e formais, incluindo as cascas e os paraboloides estruturais. Segundo Hitchcock, como em nenhuma outra parte, o "skyline curvo" era um tema recorrente. ${ }^{97}$ A coleção mostra exemplos da sua aplicação em variados programas e países: Igreja da Pampulha (Niemeyer, 1943) no Brasil e Igreja de la Purísima (Enrique de la Mora, 1947) no México; edifícios para a educação, como a Escola 
de Administração e Comércio (Guillermo de Roux, René Brenes, Ricardo Bermúdez, 1949-1953) no Panamá, o conjunto escola e ginásio do Pedregulho (Affonso Eduardo Reidy, 1948-1950) e o Instituto de Puericultura Uorge Machado Moreira, 1953), no Brasil; instalações esportivas, como a Piscina do Departamento de Esportes de São Paulo (Ícaro de Castro Mello, 1952-1953) no Brasil, o Estádio Olímpico (Carlos Raúl Villanueva, 1950-1951) na Venezuela e o Estádio de Basebol (Mesa Gabriel Solano e outros, 1947) na Colômbia; instalações industriais como os Laboratórios CIBA (Alejandro Prieto e Félix Candela, 1953-1954) no México, a Fábrica de Chicletes Clark's (Francisco Pizano, 1953) na Colômbia; e num programa recreativo, o Cabaret Tropicana (Max Borges, 1952) em Cuba (Figura 15).

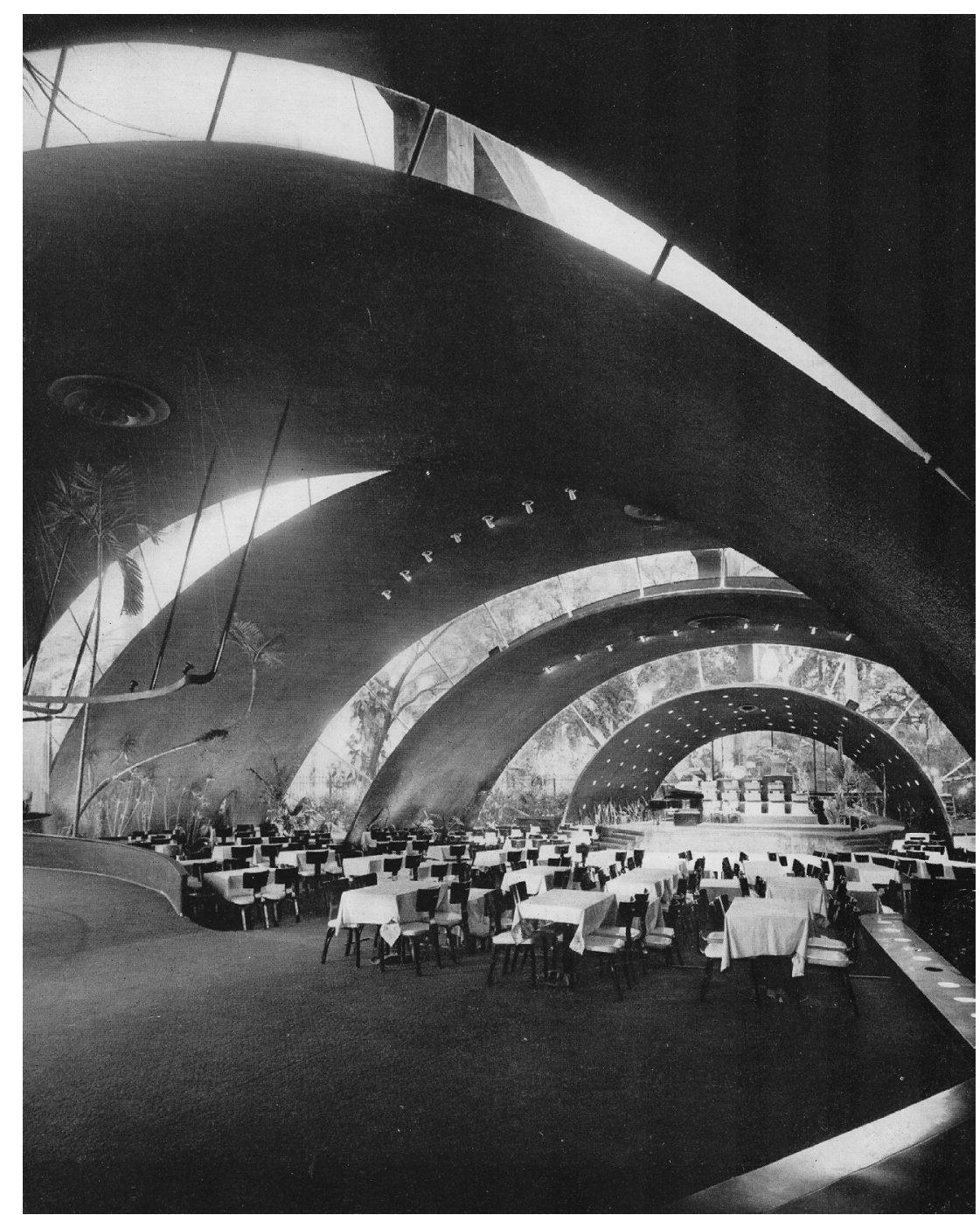

Figura 15 - Max Borges. Cabaret Tropicana, Havana, 1952. Fonte: Hitchcock (1955c). Foto: J. Alex Langley. 
98. Sobre a relação entre a curva na arquitetura moderna e o barroco, ver Comas (2005).

99. Ibid.

100. Ibid., p. 29.

101. Ibid., p. 61

102. Ibid., p. 62, tradução nossa.

103. Ibid.
"Mesmo no plano", escreve Hitchcock, "a curva é usada com mais frequência na América Latina do que nos Estados Unidos" e, no caso de Niemeyer, revela-se como "característica de uma maneira pessoal". Apesar disso, Hitchcock evita a associação direta entre a frequência relativa da curva e a herança barroca, como algum tipo de fundamento para uma identidade continental: 98

Um certo lirismo - do qual a cor e as formas curvas são ingredientes importantes, sem serem, de forma alguma, universais - parece ter um apelo contínuo ao temperamento ibérico. No entanto, é difícil apontar uma grande continuidade de sensibilidade entre a arquitetura eclesiástica incrivelmente suntuosa das colônias espanholas e portuguesas e a severidade genérica da arquitetura moderna, mesmo que tenha se desenvolvido na América Latina. ${ }^{99}$

Mas reconhece que "a arquitetura ainda é em grande medida uma arte na América Latina" e que aqueles setores sociais capazes de promover encomendas públicas (que, como ele mesmo nota, estavam longe de representar a totalidade da população) tinham expectativas que extrapolavam as soluções puramente "funcionais", de modo que há uma correspondência entre a arquitetura moderna e uma certa demanda de expressão cultural por parte das lideranças governamentais. ${ }^{100}$ No balanço final, the parecem mais significativos os grandes equipamentos públicos e os conjuntos de habitação social, do que a casa privada (que certamente era um dos pontos fortes da coleção de 1932).

Para Hitchcock, a arquitetura moderna na América Latina "tem seus próprios valores intrínsecos". ${ }^{101}$ Considerando a primeira metade do século XX em toda sua extensão, não haveria na América Latina, em comparação com Europa e América do Norte, a presença de "líderes como le Corbusier ou Wright"; porém, limitandose a observação aos anos de pós-guerra, a situação era distinta, pois a produção latino-americana excedia ambos em qualidade e número. "À lista de grandes edifícios modernos", conclui Hitchcock, "a América Latina acrescentou uma cota justa; ao conjunto da construção contemporânea realizada, acrescentou proporcionalmente mais". ${ }^{102}$

Hitchcock alega que facilmente poderia ter acrescentado ao menos mais 25 edifícios de qualidade equivalente aos selecionados. ${ }^{103}$ Assim mesmo, como em toda coleção, há peças faltantes ou peças que o colecionador quis incluir, mas não foi capaz de fazê-lo. No caso brasileiro, João Vilanova Artigas foi uma dessas peças. A correspondência mantida entre Hitchcock e Henrique Mindlin durante a preparação da exposição é larga e amigável. Hitchcock pede ajuda, relata atrasos e dificuldades, recorda a recepção calorosa no Rio, fala de amigos comuns, como 
a artista Fayga Ostrower, e atualiza Mindlin sobre o trabalho na redação do

104. Mindlin (1956).

105. Hitchcock (1955a, tradução nossa).

106. Ibid., tradução nossa.

107. Mindlin (1955, tradução nossa).

108. Bullrich (1969).

Você sabe que eu dizia que só poderíamos incluir em torno de quinze edifícios brasileiros. Na realidade, nós temos, presentemente, na lista quase definitiva, dezessete edifícios. Quatro de Oscar, dois de Reidy, dois de Levi, dois de Jorge [Moreira] e um por cada entre Costa, Bratke, Bernardes, Artigas e de Castro Mello. ${ }^{105}$

Mais adiante, pela mesma carta, sabemos qual seria a obra de Vilanovas Artigas:

Até agora esses foram os problemas do Rio, mas eu tenho alguns em São Paulo também. Quando e onde nasceu Rino Levi e onde formou-se? Quando foi construída a casa Milton Guper? Quando e onde nasceu Artigas, onde ele estudou, e qual seu endereço atual? Você poderia obter dele as plantas de seu Edifício Louveira, o prédio de apartamentos na Praça Vilaboim; ou irá ele recusar-se, como um bom comunista, a ter qualquer relação com uma empreitada capitalista, tal como essa exposição? 106

Mindlin responde em 17 de março de 1955, desempenhando-se dos pedidos, fornecendo os dados biográficos de todos e assegurando que Artigas lamentava não o haver conhecido: "he [Artigas] was very sorry - [grifado no original] - e se perguntava se isso não havia sido arranjado a propósito..." 107

O episódio destaca o caráter inevitavelmente incompleto de toda coleção. Por um lado, considerando o desenvolvimento da arquitetura latino-americana nas décadas subsequentes, o relevo posterior assumido pela figura de Artigas certamente sugere, num olhar retrospectivo, que sua ausência foi uma omissão grave. Por outro lado, a seguinte iniciativa para formular uma história abrangente da arquitetura moderna na América Latina, New Directions in Latin American Architecture, de Francisco Bullrich, publicado em 1969, no que se refere às obras construídas anteriormente a 1955, pouco ampliou a coleção de Hitchcock. ${ }^{108}$ 
109. A lista de componentes da exposição inclui ainda mais cinco obras, em Brasil (2), México (1), Panamá (1). As fotos dessas obras estão entre as ilustrações do ensaio introdutório.

110. Apenas a lâmina de número 20 , correspondente ao Edificio Valenzuela, de Ricardo de Robina e Jaime Ortiz Monasterio (México, D. F.), não inclui nenhum desenho.

111. Hitchcock (1955c, p. 44, tradução nossa).

\section{SOBRE COMO FIXAR AS BORBOLETAS}

Em sua estrutura, Latin American Architecture since 1945 compreende, além do ensaio redigido por Hitchcock, 47 lâminas dedicadas a obras de arquitetura moderna distribuídas entre Brasil (14), México (9), Venezuela (6), Colômbia (5), Cuba (3), Argentina (2), Uruguai (2), Chile (2), Porto Rico (2), Peru (1), Panamá (1). ${ }^{109}$ Essas obras estão documentadas por imagens fotográficas acompanhados de breves linhas explicativas e por uma documentação gráfica relativamente heterogênea, em diferentes escalas, revelando em geral plantas e, eventualmente, cortes, esquemas, implantações, perspectivas, maquetes. ${ }^{110}$

Nessa documentação, o protagonismo é do edifício. A escala primária de observação é a escala do edifício, mesmo quando se trata de obras que formam parte de grandes conjuntos urbanos modernos, como é o caso das cidades universitárias. À exceção da Aula Magna e da Praça Coberta, que são conjugadas, outros edifícios de Carlos Raúl Villanueva na Cidade Universitária de Caracas se mostram separadamente. Também são apresentados em separado os edifícios da Cidade Universitária do México, apesar de Hitchcock afirmar, no ensaio, que a mesma "requer consideração tanto pelo todo, quanto pelas diversas estruturas individuais" de que se compõe. ${ }^{111}$ Essa lacuna é parcialmente sanada no caso dos conjuntos habitacionais, pois pelo menos um dos registros apresentados permite a compreensão da organização geral, seja a perspectiva do Parque Guinle de Lucio Costa, a fotografia da maquete do Pedregulho de Affonso Reidy, ou os planos gerais do Cerro Piloto de Guido Bermudez, em Caracas, e do Presidente Juárez de Mario Pani, na Cidade do México.

Após a série de lâminas, há um complemento final, intitulado "Fachadas Urbanas", que se compõe de 16 edifícios de apartamentos ou escritórios, apresentados apenas através das fotografias de suas fachadas frontais, em Bogotá (4), Buenos Aires (3), São Paulo (3), Havana (2), Lima (2), Caracas (1) e México D. F. (1). Rosalie Mckenna é quem contribui com o maior número de fotografias, mas, ainda assim, elas perfazem menos da metade do total. Diversos outros fotógrafos, entre os quais se encontram nomes como Marcel Gautherot, Peter Scheier, G. E. Kidder Smith, Ezra Stoller, Walter Reuter, concorreram também para o acervo fotográfico.

Assim como o arranjo da exposição, a montagem final do catálogo foi coordenada por Drexler, e supervisionada à distância por Hitchcock, que havia viajado para a Inglaterra. Inclusive o título final parece haver sido decidido nessas condições. Em cartas a Hitchcock de setembro de 1955, Drexler menciona as dúvidas suscitadas por "Latin American Architecture, 1945-1955", o título então considerado para a exposição, sobretudo pelas duas datas específicas indicadas. 
Drexler é francamente contrário à ideia de usar "pós-guerra" no título, como ele e Hitchcock haviam feito em Built in the USA: Postwar Architecture, em 1952, expressão que não the parece fazer sentido para o catálogo latino-americano. "Latin American Architecture since 1945" surge como uma alternativa aceitável, ainda que não perfeita. ${ }^{112}$ Assim, partindo de uma ideia inicialmente similar à exposição americana, com o "Built in Latin America" considerado a princípio, o título acabou ficando mais parecido com a fórmula usada na exposição do estilo internacional em 1932, com o "desde 1945" análogo ao "desde 1922".

À primeira vista, a relação que as lâminas mantêm com o ensaio, na organização formal do catálogo, é também similar à publicação The International Style since 1922: o ensaio se restringe às primeiras páginas, enquanto as lâminas se apresentam depois, numa sequência contínua. Em seu estudo sobre a imagem, Jacques Aumont explica como a diferença entre "mostrar" e "narrar" está relacionada à existência de dois níveis potenciais de narratividade ligados às imagens. $\bigcirc$ primeiro está vinculado à imagem em si mesma e ao seu conteúdo intrínseco ou àquilo que ela mostra. $\bigcirc$ segundo se inserta precisamente na sequência de imagens ou na maneira como elas estão ordenadas. A narrativa, segundo Aumont, se inscreve menos no tempo que na ordem. ${ }^{13}$ Tomando o catálogo Latin American Architecture since 1945 como uma coleção, a sua dimensão narrativa reside também no seu caráter de álbum fotográfico ou na sequência, na posição em que as peças estão fixadas, umas com relação às outras. E quanto à ordem, há diferenças com relação ao catálogo de 1932.

No catálogo de 1955, a narrativa por imagens não está organizada nem cronológica nem geograficamente, como de certo modo faz o ensaio, ao assumir em determinadas partes do texto a estruturação do discurso por países ou cidades. A narrativa também não está ordenada pelo critério da autoria, como era o caso da automática ordem alfabética adotada no catálogo de 1932. Os arquitetos aparecem num dado momento e podem reaparecer algumas lâminas adiante. Mas o movimento da narrativa não é aleatório ou neutro como em 1932. Existe um sentido proposto nessa organização, que tem relação com as implicações programáticas dos edifícios e, eventualmente, com nexos tipológicos. Poderíamos mesmo dizer, com as suas funções, mas seria preciso advertir que não se trata de dispor do "habitar, trabalhar, recrear, circular" da Carta de Atenas para produzir, implicitamente, categorias classificatórias.

A coleção inicia pela capela da Pampulha de Oscar Niemeyer (Figura 16), seguida das igrejas de Enrique de la Mora no México e Henry Klumb no Panamá (lâminas 1-3). Passa aos equipamentos institucionais e grandes infraestruturas urbanas, dentre os quais se destacam os edifícios construídos nas cidades universitárias (México, Caracas, Bogotá, Rio de Janeiro e Panamál, como a biblioteca de Juan O'Gorman,
112. Drexler (1955a, 1955b).

113. Cf. Aumont, op. cit., p. 245-246. 
Figura 16 - Oscar Niemeyer. Igreja de São Francisco, Pampulha, 1943. Fonte: Hitchcock (1955c). Foto: Marcel Gautherot.

a Aula Magna de Carlos Raúl Villanueva (Figura 17), o Instituto de Puericultura de Jorge Moreira, os estádios de Augusto Pérez Palacios, Carlos Raúl Villanueva (Figura 18), Mesa Gabriel Solano, entre outros exemplos (lâminas 4-15). Inclui, a seguir, um par de edifícios industriais, os laboratórios CIBA de Alejandro Prieto e Félix Candela no México e a fábrica de chicletes Clark's de Francisco Pizano na Colômbia llâminas 16-17), e o clube noturno de Max Borges em Cuba (lâmina 18).

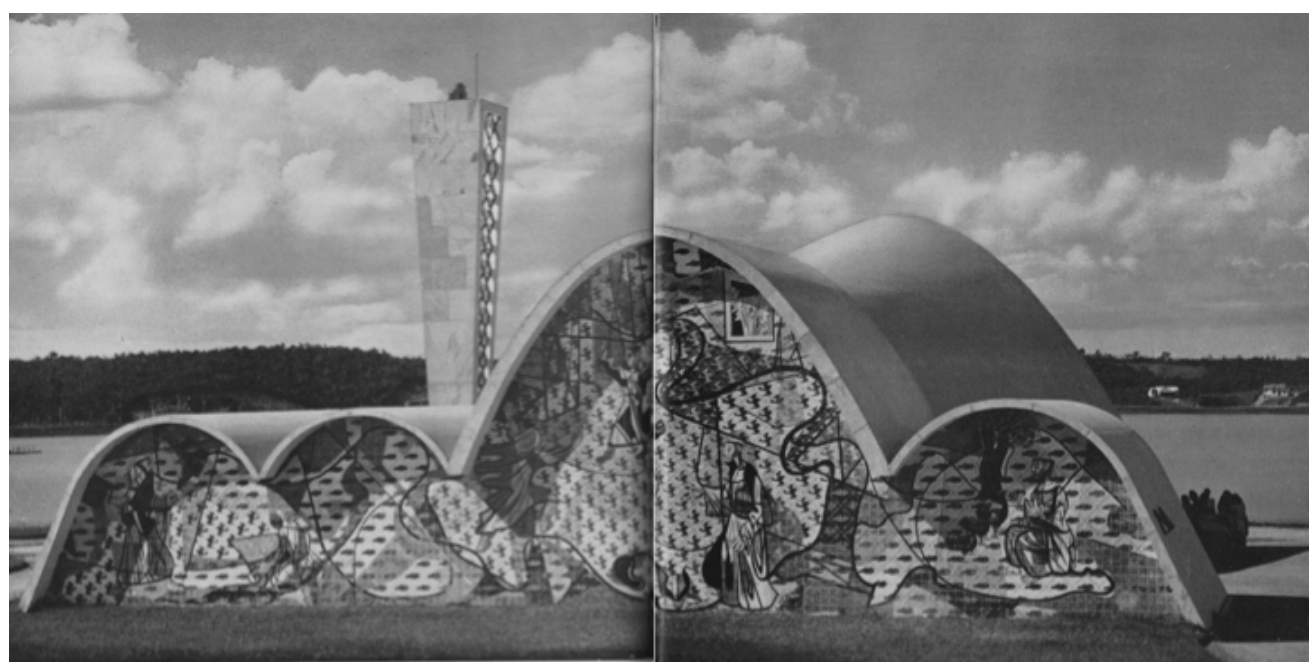

Figura 17 - Carlos Raúl Villanueva, Aula Magna, Cidade Universitária de Caracas, 1952-1953. Fonte: Hitchcock (1955c). Foto: Rosalie Mckenna.

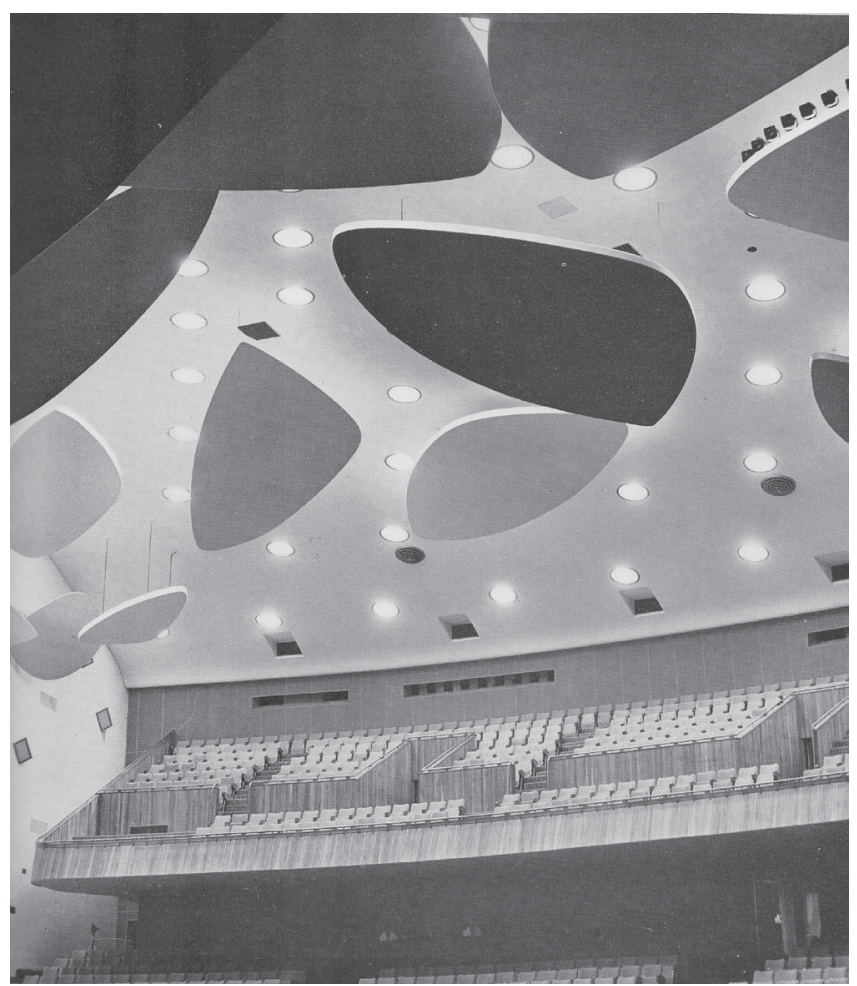




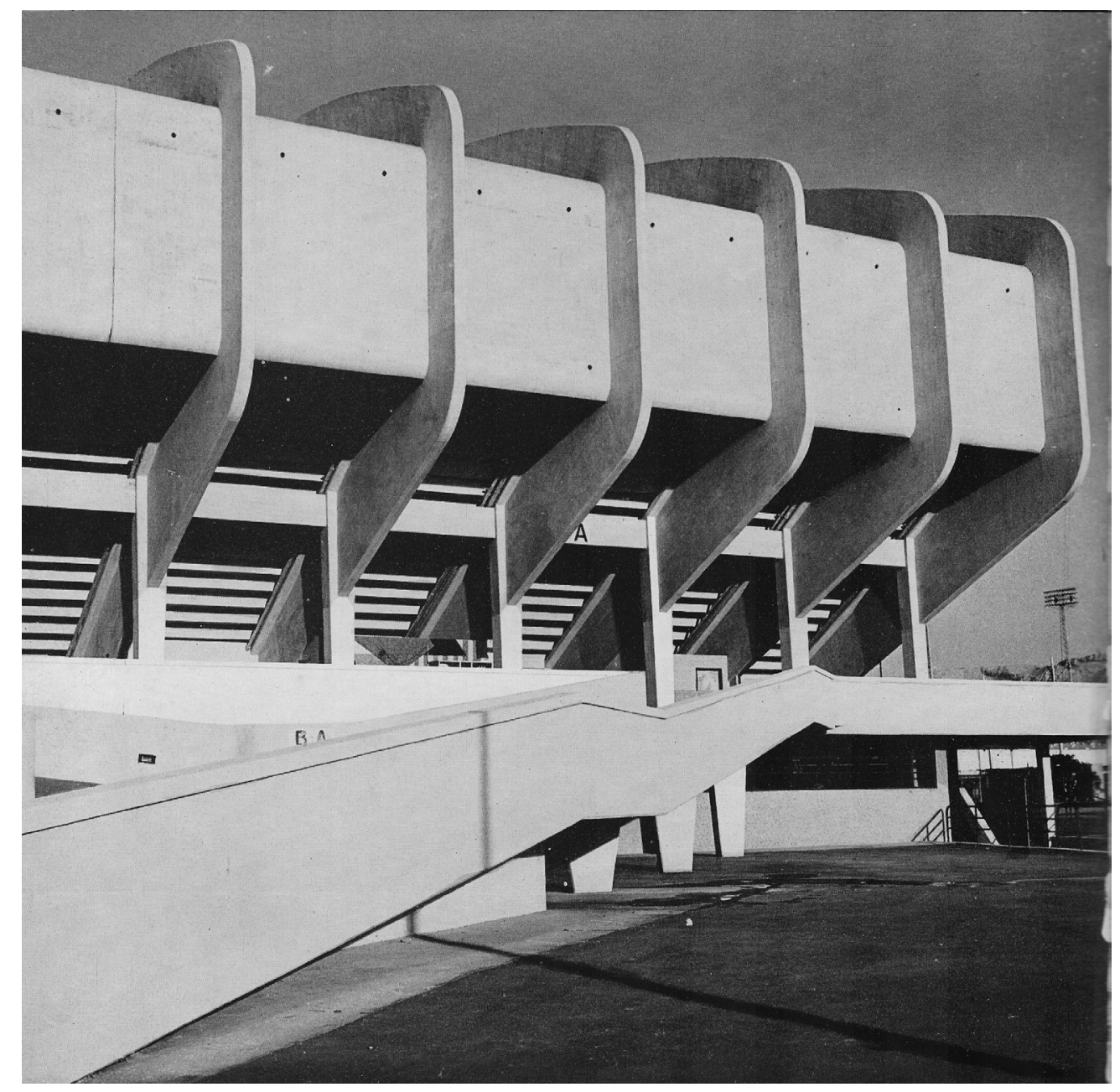

Figura 18 - Carlos Raúl Villanueva, Estádio Olímpico, Cidade Universitária de Caracas, 19501951. Fonte: Hitchcock (1955c). Foto: Rosalie Mckenna.

Os exemplos que seguem são edifícios de escritórios urbanos: o Banco Boavista de Niemeyer no Rio de Janeiro; o edifício Valenzuela de Ricardo de Robina e Jaime Ortiz Monastério no México D. F. (Figura 19); e o edifício Polar de Martin Vegas e José Miguel Galia em Caracas (lâminas 19-21) (Figura 20). Os dois exemplos seguintes, o hospital de Rino Levi e Roberto Cerqueira César em São Paulo (lâmina 22) e o hotel de Toro, Ferrer e Torregrossa em Porto Rico (lâmina 23), são a transição para os programas essencialmente residenciais. Primeiro, se apresentam as formas de organização coletiva da habitação: os grandes conjuntos de habitação de Mario Pani (México D. F.), Affonso Eduardo Reidy (Rio de Janeiro), Guido Bermúdez (Caracas) (Figura 21 ) ou Santiago Agurto (Lima); os alojamentos para a aeronáutica de Oscar Niemeyer em São José dos Campos; o conjunto de 
casas em fita de Cuellar, Serrano e Gómez em Bogotá; o Parque Guinle de Lucio Costa no Rio; os edifícios de apartamentos isolados como os blocos de Raúl Sichero em Montevideo (Figura 22), Jorge Moreira no Rio, Guinand e Benacerraf em Caracas (lâminas 24-35). Logo segue a sequência de casas isoladas, que inclui obras de Le Corbusier e Amancio Williams na Argentina; Antonio Bonet no Uruguai; Oscar Niemeyer, Henrique Mindlin, Oswaldo Bratke e Sergio Bernardes no Brasil; Jorge Costabal e Emilio Duhart no Chile; Juan Sordo Madaleno (Figura 23), Luis Barragán e Francisco Artigas no México (lâminas 36-47).

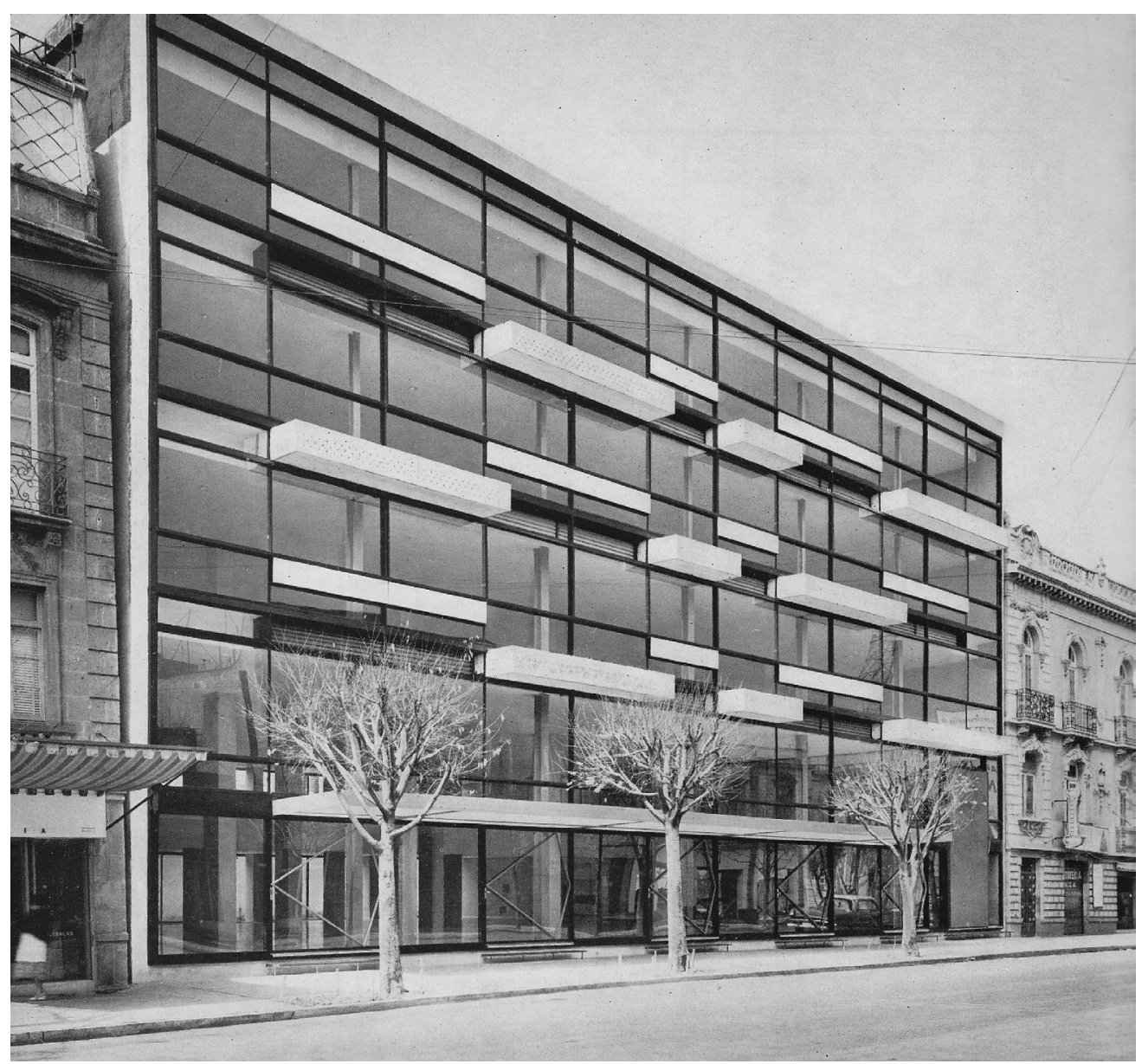

Figura 19 - Ricardo de Robina e Jaime Ortiz Monasterio. Edifício Valenzuela, México D. F. Fonte: Hitchcock (1955c). Foto: Armando Salas Portugal. 


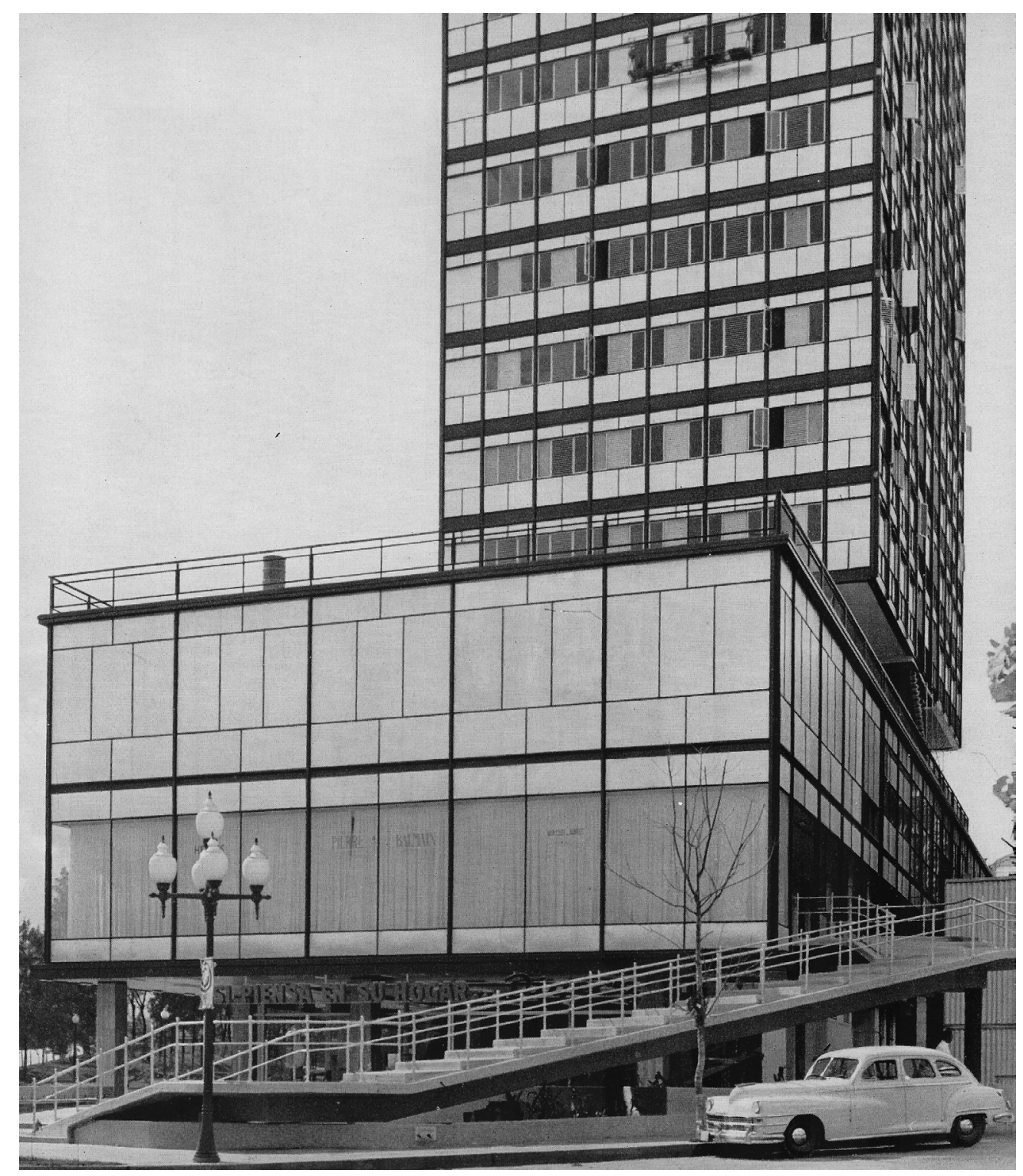

Figura 20 - Martin Vegas Pacheco e José Miguel Galia. Edifício Polar, Caracas, 1952-54. Fonte: Hitchcock (1955c). Foto: Rosalie Mckenna. 


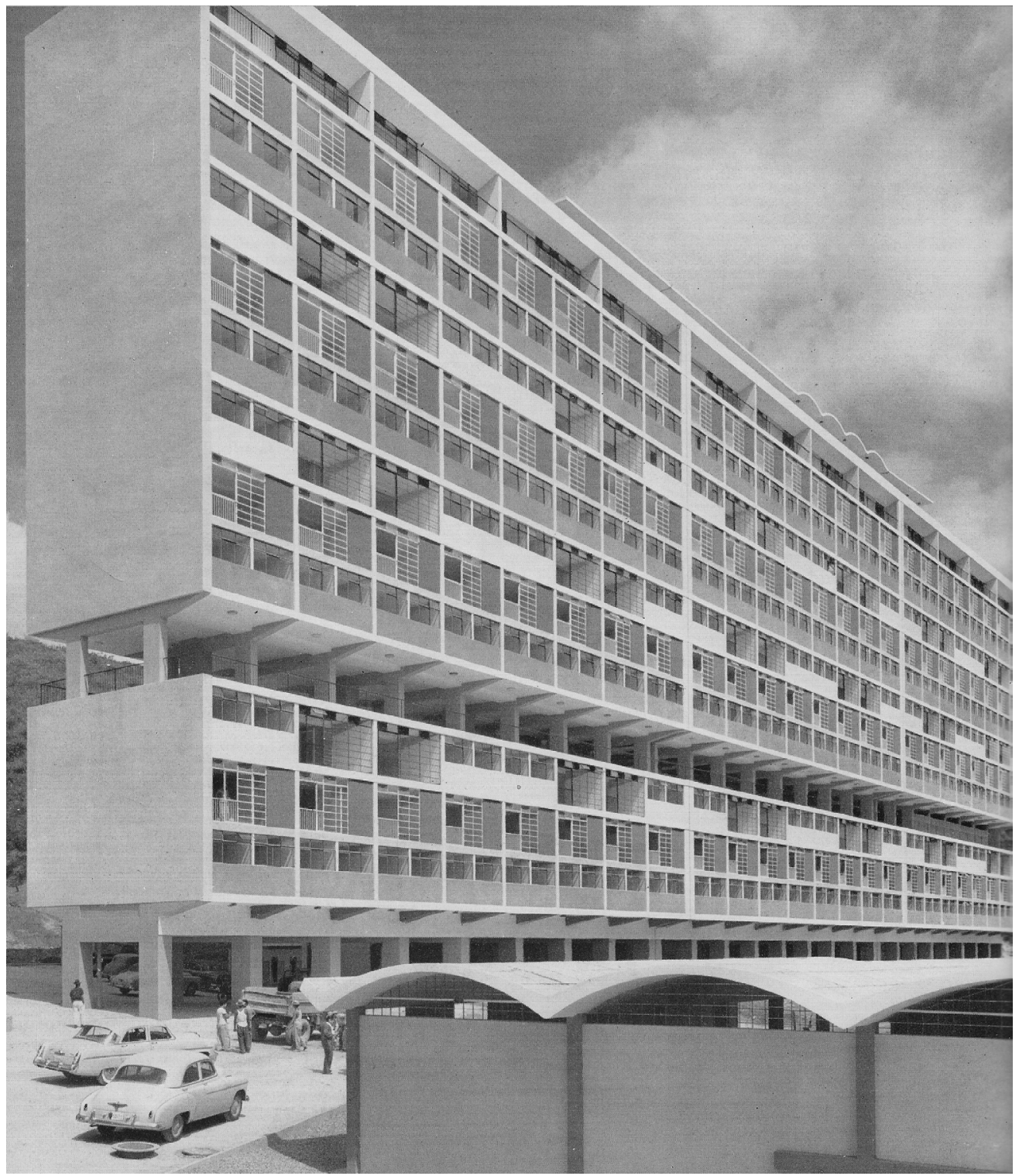

Figura 21 - Guido Bermúdez. Unidade de Habitação Cerro Grande, Caracas, 1951-1954. Fonte: Hitchcock (1955c). Foto: Rosalie Mckenna. 


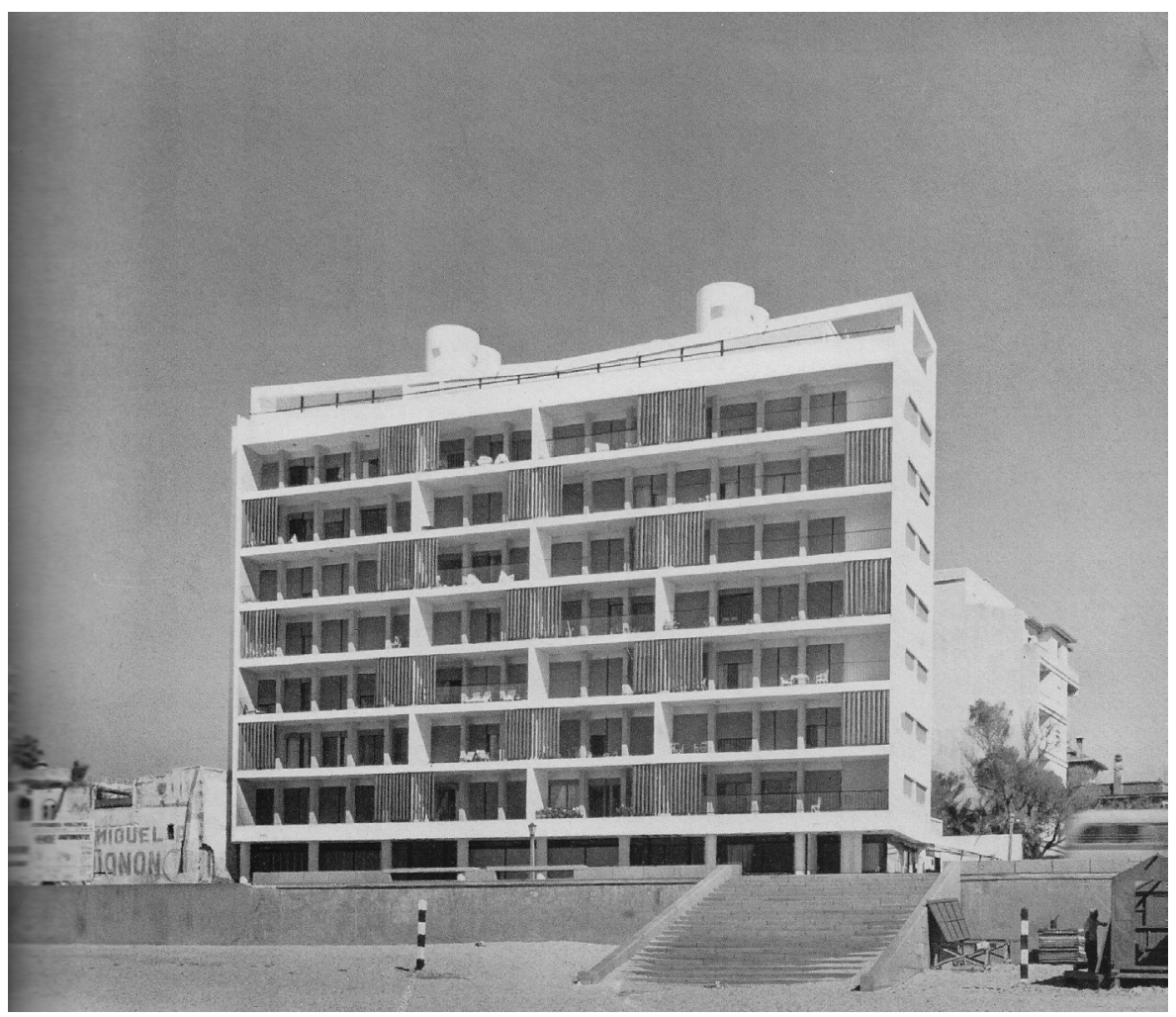

Figura 22 - Raúl Sichero. Edifício Rambla y Guayaquí, Montevideo, 1952. Fonte: Hitchcock (1955c). Foto: Rosalie Mckenna.

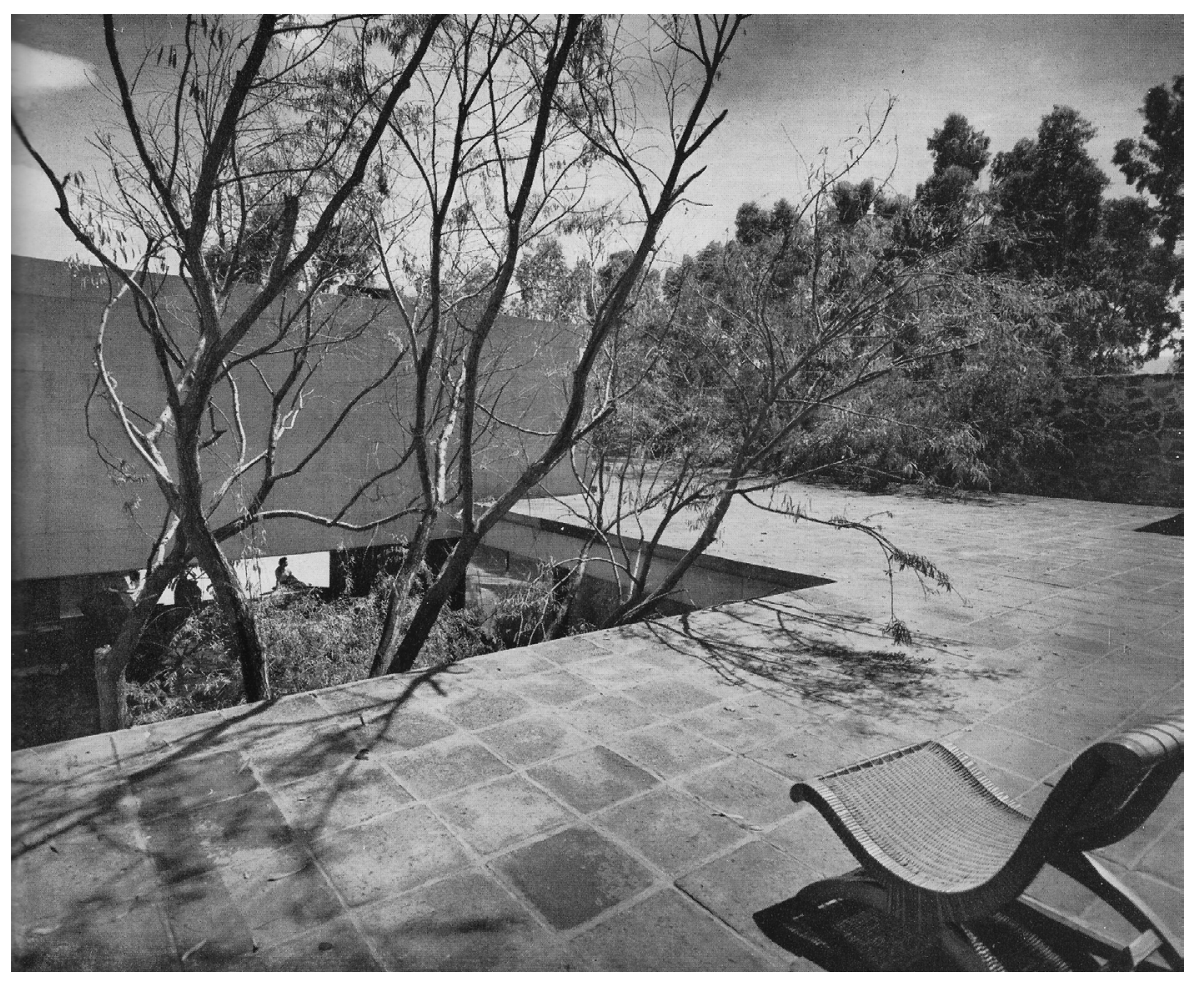

Figura 23 - Juan Sordo Madaleno. Casa do arquiteto, México D. F., 1951 52. Fonte: Hitchcock (1955c). Foto: Guillermo Zamora. 

dução nossa).

O movimento da narrativa deixa em segundo plano o dado nacional lque poderia, eventualmente, enfatizar particularidades locais), a sucessão temporal (que poderia, eventualmente, sugerir cadeias de influências) e mesmo a importância relativa dos autores, a despeito de alguns comparecerem com mais obras que outros. A ordem da narrativa acentua os rasgos homogêneos de uma realidade continental, ao organizar a coleção por programas, em sua maior parte reformulados à escala de novas demandas provocadas pelos processos de modernização a que estão submetidas as sociedades latino-americanas. A própria coleção se converte numa narrativa sobre sociedades pujantes, em que a arquitetura foi chamada à tarefa de reconstrução da realidade física. Assim, se por um lado certas peças da coleção obrigam a reconsiderar a fórmula do estilo internacional, declarada curta perante as ampliações, pelo visto possíveis, de repertórios e estratégias, por outro, a narrativa reafirma a noção de uma modernidade comum, existindo por trás das particularidades nacionais. E, nesse sentido, reafirma uma das bandeiras de 1932.

Ainda cabem alguns comentários sobre o apartado final, a sequência de 16 edifícios exibidos lado a lado, através apenas das fotografias de suas fachadas frontais, e seu significado nessa narrativa. Por carta, Drexler diz a Hitchcock que planeja dispor a série de fachadas ao final do livro, tal como na proposta de layout enviada a ele em anexo, e pede que Hitchcock providencie um parágrafo explicando de que se trata. ${ }^{114}$ Pela resposta de Hitchcock compreendemos que, embora tenha deixado a Drexler as decisões finais sobre o layout, ele de fato definiu a ordem das imagens:

\footnotetext{
Para que eu possa fazer referências específicas às diferentes fachadas, elas estão marcadas por letras, na sequência que me pareceu mais desejável. Eu suponho que você irá providenciar sob cada série uma lista com os nomes dos edifícios e arquitetos. Receio que nos faltem algumas datas, mas para estas notas isso não é tão importante. Eu mantive meu texto tão curto quanto me foi possível, à custa de ser um pouco brusco no estilo. Não está muito claro para mim se o texło será impresso todo em um só lugar, ou se vai ser dividido ao longo das três séries. Acredito que seria melhor se ele pudesse ser lido continuamente, mas isso é em parte um problema de layout. ${ }^{115}$
}

Ao contrário dos variados exemplares anteriores, essas 16 peças da coleção são basicamente similares, de um ponto de vista programático e tipológico. Elas correspondem a um padrão de edifícios de vários pavimentos, na maioria de escritórios, mas também de apartamentos, sem que essa distinção seja necessariamente evidente nas fachadas. Também são similares em seu papel urbano: correspondem ao que se poderia considerar como edifícios destinados a 
compor o tecido conjuntivo da cidade, como parte da massa regular contra a qual eventualmente se destacam os programas excepcionais.

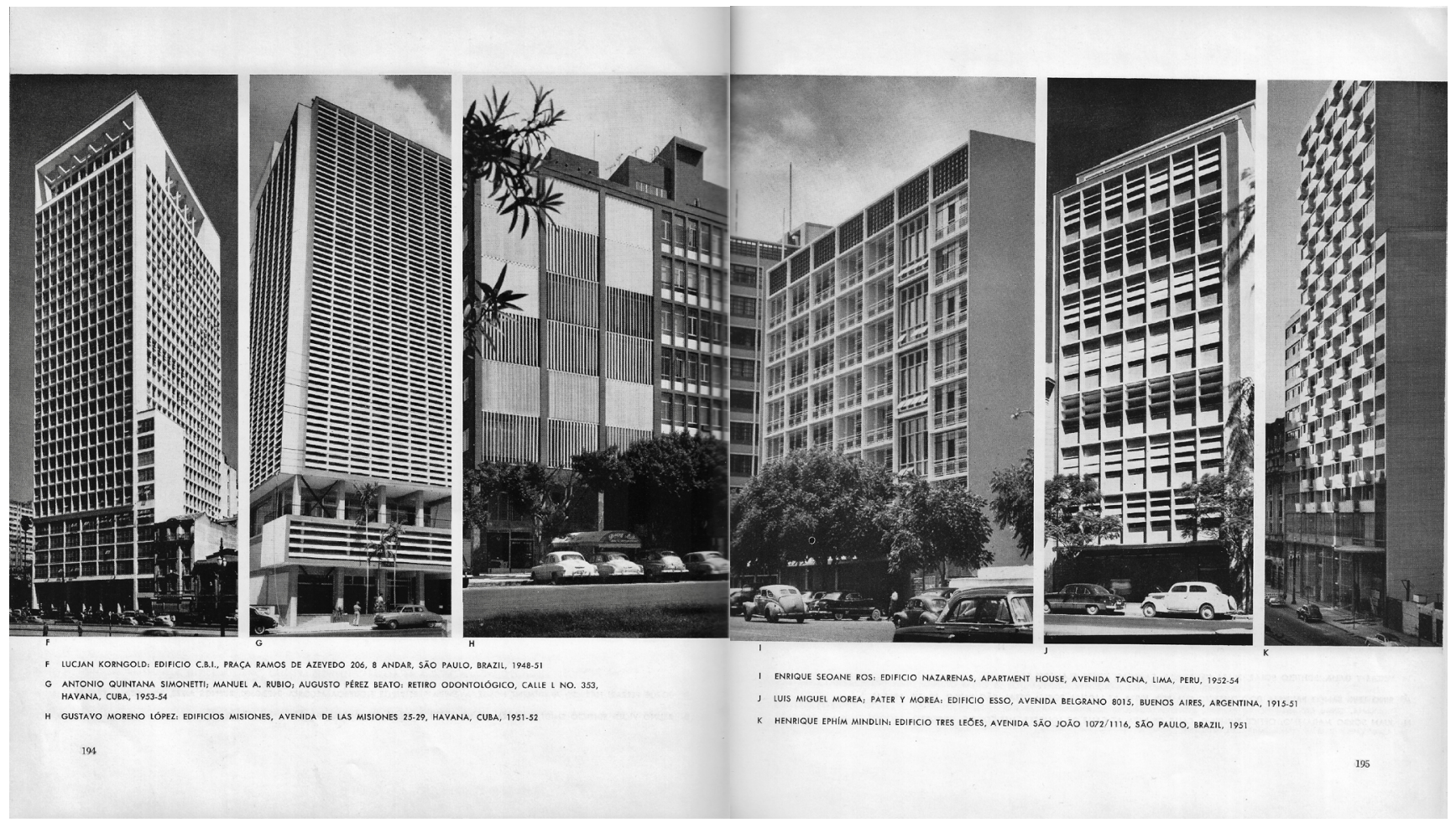

Figura 24 - Fachadas urbanas (edifícios em São Paulo, Havana, Lima, Buenos Aires). Fonte: Hitchcock (1955c).

Eles se apresentam em três séries, cada uma delas dispostas sobre duas páginas contíguas. A disposição das imagens sobre a página reforça a ideia de fachada urbana; mostra-se a fachada frontal de cada edifício, em fotografias tomadas de pontos de vista similares, tratando de abarcar a altura total dos edifícios, apresentados como partes compatíveis para a composição de realidades urbanas análogas. A composição evoca a rua como conjunto de edifícios (Figura 24). Essas séries demonstram três maneiras gerais de abordar o problema da grande fachada (seja no que se refere à questão da estratificação, seja das relações entre a estrutura e a envolvente), como três grandes temas compositivos, cujas diferentes variações são sustentadas pelos exemplos. Na primeira série predomina a estratificação horizontal, seja porque se evidenciam as lajes, seja porque se dividem as fachadas entre cintas equivalentes de peitoris cheios e janelas em fita. Na segunda série se mostram as fachadas espessas, do tipo grelha, habilitadas pela estrutura de concreto armado, e que geralmente incorporam elementos de proteção solar em ricas texturas e variações plásticas. Na terceira 
116. Hitchcock (1955c, p. 191, tradução nossa).

117. Hitchcock (1955c, p. 61).

118. Barr et al. (1948, p. 5).

119. Sobre a formação acadêmica de Hitchcock ver Searing (1990). Segundo a autora, Hitchcock graduou-se em 1924 e frequentou a escola de arquitetura em Harvard. Mas, como ele mesmo escreveu em Harvard Class Notes (1949), achou o trabalho na história da arquitetura com Arthur Kingsley Porter mais interessante e logo desistiu de tornar-se arquiteto (SEARING, 1990, p. 253). série predominam as fachadas leves, em que os edifícios são envolvidos por planos contínuos, formados por painéis envidraçados ou opacos, montados em caixilharias metálicas. "Mais e mais" - observa Hitchcock sobre esse conjunto - "os tipos articulados de fachada estão suplantando o modo mais plano herdado dos anos 1920," reconhecendo nesses exemplos uma "harmonia geral de caráter, sem a monotonia que se poderia recear". ${ }^{116}$

As "Fachadas Urbanas" - título que provavelmente não soaria tão bem em 1932 - correspondem a uma cidade latino-americana que existe e não existe. Os edifícios obviamente existem, mas a cidade moderna que sugerem é em parte construída pela narrativa; somente no espaço manipulado da coleção é que arquiteturas subtraídas de seus contextos originais podem ser reordenadas em ruas latino-americanas que combinam um pedaço de Lima com uma esquina no Rio de Janeiro, afirmando a ideia de "common front" defendida por Hitchcock. 117

Valem todas as acepções: frente comum de batalha para a arquitetura moderna, fachada corrente para a cidade moderna. Entretanto, ao colocar essas figuras lado a lado, montando ruas inexistentes, mas possíveis, de uma cidade latino-americana em parte fictícia, mas em parte real (dado que a fotografia é sempre um certificado de presença), a narrativa torna evidente uma imagem de modernidade para a qual a Europa, nesse momento, provavelmente não tinha qualquer equivalente, a despeito de que a "disciplina de estrutura e desenho" de que estamos falando tenha ali amadurecido por primeira vez.

\section{CONSIDERAÇÕES FINAIS}

No simpósio organizado pelo MoMA em 1948, What is happening to modern architecture?, Alfred Barr, na capacidade de Diretor das Coleções do Museu, esclarecia que não era arquiteto, nem crítico, nem historiador da arquitetura, mas sim uma espécie de espectador, e que havia sido desse ponto de vista, do "banco de trás", que havia escrito o prefácio para o catálogo The International Style since 1922 em 1932. ${ }^{118}$ Hitchcock, em compensação, era sim um historiador da arquitetura profissional, treinado em Harvard, e sua obra exemplifica a cooperação entre o aparato crítico, teórico e metodológico da historiografia, e o papel do museu. 119

Mas que tipo de história é Latin American Architecture since 1945? Não obstante o seu indiscutível lugar de referência para a historiografia, o catálogo não 
é propriamente a história completa da arquitetura moderna na América Latina. Não se posiciona na tradição dos grandes relatos, abrangentes e circunstanciados, que fazem a crônica dos acontecimentos, identificam cadeias de causas e efeitos e procuram explicar a complexa rede de circunstâncias externas que oferecem uma parte das condições necessárias à realização de determinadas obras num dado momento e lugar. Latin American Architecture since 1945 decorre de uma coleção; é a expressão de um recorte, que não é apenas de ordem temporal, como o título poderia sugerir. Não é o retrato de toda a arquitetura praticada na América Latina nesse período, mas de uma certa arquitetura que, naquele momento, aqui prosperou. Se há aspectos materiais comuns a essa arquitetura - como a prevalência do concreto armado - tampouco é a faceta técnica o critério formativo da coleção. Como na pequena "From Le Corbusier to Niemeyer", as escolhas têm a ver sobretudo com a forma dos edifícios e com a relação que eles sustentam com uma certa ideia de arquitetura moderna que, tal como se adverte pelas inflexões no pensamento de Hitchcock entre a estreia de 1932 e o ano de 1955, era, em si mesma, um projeto em contínua elaboração.

Do ponto de vista da historiografia, a posição de Hitchcock pode ser considerada herdeira das perspectivas formalistas que se consolidaram a partir de meados do século XIX, como reação à concepção heterônoma da arte. Foi através dessas perspectivas que a história da arte deixou de ser um fenômeno subsidiário à história política e social das nações e passou a refletir sobre um objeto de estudo próprio, diretamente associado à concepção da forma, em suas múltiplas manifestações. ${ }^{120}$

catálogo é uma narrativa desde a forma, o que não deixou de valer críticas a Hitchcock. Porém, como destacou Searing, num tempo em que a "história da arquitetura" parece em risco de se transformar numa "história sem arquitetura", numa nova dependência dos discursos econômicos, sociais, filosóficos, o trabalho de Hitchcock retém um sentido de concentração na forma construída como matéria própria da arquitetura. ${ }^{121}$ Não obstante, ver essa característica como deficiência talvez oculte a sua capacidade para produzir evidências. Ao contrário de "From Le Corbusier to Niemeyer", não se trata apenas de um par de casas para refinados conhecedores de arte e arquitetura. Considerando-se a articulação narrativa entre as imagens, no plano visual, o catálogo latino-americano reúne evidências amplas e concretas da repercussão da arquitetura moderna sobre distintos programas urbanos e da relação entre essas arquiteturas e os vetores de transformação social e modernização na América Latina.

Entretanto, na coletânea Latin America in its Architecture, publicada em 1981, Roberto Segre parte do catálogo latino-americano de Hitchcock para marcar
120. Cf. Pérez Carreño (1996).

121. Searing (1990, p. 259). 
122. Segre (1981, p. 12).

123. Toca (1990, p. 7); Gutierrez (1989).

124. Segawa (2005, p. 50).

125. Cf. Pérez Oyarzun (1991); Comas (1998); Segawa (2005); Bergdoll et al. (2015).

126. "O espaço mais significativo do Rex acusa uma incômoda similitude com seu equivalente do Radio City", escrevem Petrina e Larrañaga sobre o cinema de Alberto Prebisch em Buenos Aires (1937), comparado ao Radio City Music Hall no Rockefeller Center (New York, 1932) (TOCA, 1990, p. 173). uma distância crítica, que precisamente confronta essas ambições modernas de reconstrução da sociedade com as circunstâncias reais de acirramento das contradições sociais. ${ }^{122} \bigcirc$ argumento de Segre não era alheio à perspectiva generalizada, no âmbito internacional, de uma crise global do projeto moderno. Para alguns, prova de incapacidade da arquitetura moderna para colocar em prática as ambições do "projeto moderno", como projeto civilizador, em que a técnica seria uma força capaz de conduzir ao progresso social. Para outros, no que se refere ao caso latino-americano, essa "incapacidade" frequentemente apareceria associada a uma visão da América Latina como continente subdesenvolvido, historicamente incapaz de resolver as próprias contradições.

Na historiografia latino-americana, os anos 1980 alavancaram um conjunto de temas de fundo social, centrados na questão de uma perseguida identidade latino-americana, em geral de sentido crítico com respeito à faceta universalizante da arquitetura moderna. A visão crítica seria aquela capaz de denunciar a "implantação de valores e modelos culturalmente alheios". ${ }^{23}$ Hugo Segawa assinalou a relação entre esse ideário e os Seminários de Arquitectura Latinoamericana (SAL), onde se manejaram questões como dependência, marginalização e oposição entre centro e periferia. ${ }^{124}$ Mas, simultaneamente, uma segunda posição pode ser encontrada numa série de obras que buscaram a reconsideração histórica e formal da arquitetura moderna na América Latina, produzindo um deslocamento da ideia de identidade, como conceito articulador, para a ideia de modernidade como uma experiência comum. Esse reconhecimento crítico do legado moderno, baseado em ampla pesquisa documental, ganha ímpeto também a partir dos anos 1980 e segue presente, muitas vezes associado a redes nacionais e internacionais para a conservação e preservação da arquitetura moderna, como é o caso de Docomomo IInternational Working Party for Documentation and Conservation for Buildings, Sites and Neighborhoods of the Modern Movement), buscando rebater-se sobre as políticas de preservação do patrimônio cultural e material. ${ }^{125}$

De acordo com a primeira posição, implicitamente, a relação entre o catálogo Latin American Architecture since 1945 e a realidade seria frágil e parcial, e provavelmente a ordem da narrativa devesse ser corrigida, destacando-se os contextos nacionais e enfatizando-se aqueles exemplos livres de "incômodas similitudes" com seus antecedentes não latinos. ${ }^{26}$ Mas de acordo com a segunda posição historiográfica, o relativo absorvimento de peculiaridades locais por um fio narrativo generalizador, tal como ocorreu no catálogo de 1955, não seria um sinônimo de achatamento ou de incapacidade para ver diferenças. Ao contrário, esse fio narrativo, ao sublinhar precisamente correspondências e destacar o 
vocabulário comum do estilo internacional, atualizado e alargado na América Latina, território não mapeado em 1932, é que permite situar a contribuição latinoamericana em relação ao desenvolvimento de uma tradição moderna, como esforço coletivo e internacional. "Em parte, a arquitetura moderna cresceu seguindo líderes - Le Corbusier, Gropius, Mies, Frank Lloyd Wright - ", afirma Hitchcock, "mas também cresceu sempre de frentes mais amplas. Para o bem ou para o mal, é internacional em seu futuro". ${ }^{127}$ A coleção de 1955 atesta pela sobrevivência do estilo internacional, através da superação do cânon de 1932 por frentes que estavam fora do mapa em 1932. Na mesma medida, ela mostra como a recusa à uniformidade do "academicismo", para usar a expressão de Hitchcock, aconteceu mais além do (limitado) viés da identidade.
127. Hitchoock (1955c, p. $61)$. 


\section{REFERÊNCIAS}

FONTES MANUSCRITAS

DREXLER, Arthur. [Correspondência]. Destinatário: Henry-Russell Hitchcock. New York, 5 set. 1955. The Museum of Modern Art Exhibition Records, 590.2. New York: The Museum of Modern Art Archives, 1955a.

DREXLER, Arthur. [Correspondência]. Destinatário: Henry-Russell Hitchcock. New York, 19 set. 1955. The Museum of Modern Art Exhibition Records, 590.2. New York: The Museum of Modern Art Archives, 1955b.

FROM LE CORBUSIER TO NIEMEYER. Captions. The Museum of Modern Art Exhibition Records, 400.4. New York: The Museum of Modern Art Archives, 1949a.

FROM LE CORBUSIER TO NIEMEYER. Installation Notes. The Museum of Modern Art Exhibition Records, 400.4. New York: The Museum of Modern Art Archives, 1949b.

FROM LE CORBUSIER TO NIEMEYER. Layout sketch. The Museum of Modern Art Exhibition Records, 400.4. New York: The Museum of Modern Art Archives, 1949c.

FROM LE CORBUSIER TO NIEMEYER. Press Release. Museum Exhibits Architectural Models and Plans. "From Le Corbusier to Niemeyer". The Museum of Modern Art Exhibition Records, 400.4. New York: The Museum of Modern Art Archives, 1949d.

HITCHCOCK, Henry-Russell. [Correspondência]. Destinatário: Henrique Mindlin. New York, 14 jan. 1955. The Museum of Modern Art Exhibition Records, 590.2. New York: The Museum of Modern Art Archives, 1955a.

HITCHCOCK, Henry-Russell. [Correspondência]. Destinatário: Arthur Drexler. Londres, 12 out. 1955. The Museum of Modern Art Exhibition Records, 590.2. New York: The Museum of Modern Art Archives, 1955b.

LATIN AMERICAN ARCHITECTURE SINCE 1945. For release: Wednesday, November 23, 1955. Press Preview: Tuesday, November 22. The Museum of Modern Art Exhibition Records, 590.2. New York: The Museum of Modern Art Archives, 1955a.

LATIN AMERICAN ARCHITECTURE SINCE 1945. Plan. The Museum of Modern Art Exhibition Records, 590.5. New York: The Museum of Modern Art Archives, [1955b].

MINDLIN, Henrique. [Correspondência]. Destinatário: Henry-Russell Hitchcock. Rio de Janeiro, 17 mar. 1955. The Museum of Modern Art Exhibition Records, 590.2. New York: The Museum of Modern Art Archives, 1955. 
MODERN ARCHITECTURE: INTERNATIONAL EXHIBITION. Master Checklist. The Museum of Modern Art Exhibition Records, 15. New York: The Museum of Modern Art Archives, [1931a].

MODERN ARCHITECTURE: INTERNATIONAL EXHIBITION. Press release. January 24, 1931. The Museum of Modern Art Exhibition Records, 15. New York: The Museum of Modern Art Archives, 1931b.

MODERN ARCHITECTURE: INTERNATIONAL EXHIBITION. Press release. November 27, 1931. The Museum of Modern Art Exhibition Records, 15. New York: The Museum of Modern Art Archives, 1931c.

MODERN ARCHITECTURE: INTERNATIONAL EXHIBITION. Press release, s/d. The Museum of Modern Art Exhibition Records, 15. New York: The Museum of Modern Art Archives, [1931d].

LIVROS, ARTIGOS E TESES

AUMONT, Jacques. A imagem. Campinas: Papirus, 1993.

BARR, Alfred et al. What is happening to Modern Architecture? A symposium at the Museum of Modern Art. The Bulletin of the Museum of Modern Art, New York, v. 15, n. 3, p. 4-20, 1948. Doi: <https://doi.org/10.2307/4058109>.

BARR, Alfred. Preface. In: HITCHCOCK, Henry-Russell; JOHNSON, Philip. The international style: architecture since 1922. New York: W. W. Norton \& Company, 1966. p. 11-16.

BARTHES, Roland. A câmara clara: notas sobre a fotografia. Lisboa: Edições 70, 1980.

BERGDOLL, Barry. Good neighbors: The Museum of Modern Art and Latin America, 1933-1955, a journey through the MoMA Archives. In: NOELLE, Louise; SAN MARTÍN, Iván (comp.). Modernidad urbana: urban modernity. México, DF: Docomomo, 2012. p. 41-75.

BERGDOLL, Barry; COMAS, Carlos Eduardo; LIERNUR, Jorge Francisco; REAL, Patricio del. Latin American in construction: architecture 1955-1980. New York: The Museum of Modern Art, 2015.

BERGDOLL, Barry; CHRISTENSEN, Peter. Home delivery: fabricating the modern dwelling. New York: The Museum of Modern Art, 2008.

BULLRICH, Francisco. New directions in Latin American architecture. New York: George Braziller, 1969. 
CABRAL, Cláudia Costa. Arte e arquitetura moderna em três projetos do Oscar Niemeyer. In: ESPINOZA, José Carlos Huapaya (org.). Revisões e ampliações da arquitetura e do urbanismo modernos no Brasil. Salvador: Edufba, 2020. p. 85-110.

CABRAL, Cláudia Costa. La revista como escudo. Módulo y Oscar Niemeyer. In: TORRENT, Horacio (comp.). Revistas, arquitectura, y ciudad. Representaciones en la cultura moderna. Pamplona: T6) Ediciones, 2013. p. 49-70.

COMAS, Carlos Eduardo Dias. Brazil builds e a bossa barroca: notas sobre a singularização da arquitetura moderna brasileira. In: SEMINÁRIO DOCOMOMO BRASIL, 6., 2005, Niterói. Anais [...]. Niterói: UFF, 2005. p. 1-21.

COMAS, Carlos Eduardo Dias. La revista como lanza. Habitat y Lina Bo Bardi. In: TORRENT, Horacio (comp.). Revistas, arquitectura, y ciudad. Representaciones en la cultura moderna. Pamplona: T6) Ediciones, 2013. p. 33-47.

COMAS, Carlos Eduardo Dias. Memorandum latinoamericano: la ejemplaridad arquitectónica de lo marginal. 2G, Barcelona, n. 8, p. 129-143, 1998.

GOODWIN, Philip Lippincott; SMITH, G. E. Kidder. Brazil builds: architecture new and old, 1652-1942. New York: The Museum of Modern Art, 1943.

GUTIÉRREZ, Ramón. Arquitectura latino-americana: textos para reflexão e polêmica. São Paulo: Nobel, 1989.

HITCHCOCK, Henry-Russell; JOHNSON, Philip. The international style: architecture since 1922. New York: W. W. Norton \& Company, 1932-1966.

HITCHCOCK, Henry-Russell. Some problems in the interpretation of modern architecture. Journal of the Society of Architectural Historians, Berkeley, v. 2, n. 2, p. 29-32, 1942. Doi: <https://doi.org/10.2307/901237>.

HITCHCOCK, Henry-Russell. The architecture of bureaucracy and the architecture of genius. The Architectural Review, London, v. 101, n. 60, p. 2-6, 1947.

HITCHCOCK, Henry-Russell. Painting toward architecture. New York: Duel, Sloan and Pearce, 1948.

HITCHCOCK, Henry-Russell. The international style twenty years after. Architectural Record, [s. l.], v. 110, n. 2, p. 89-97, 1951.

HITCHCOCK, Henry-Russell. Latin American architecture since 1945. New York: The Museum of Modern Art, 1955c. 
HITCHCOCK, Henry-Russell; DREXLER, Arthur. Built in the USA: postwar architecture. New York: Simon \& Schuster, 1952.

HUYGHE, René. Prefácio. In: Enciclopédia dos museus: Louvre Paris. São Paulo: Melhoramentos, 1967. p. 10-15.

LIRA, José. Warchavchik: fraturas da vanguarda. São Paulo: Cosac Naify, 2011.

MAX BILL, o inteligente iconoclasta. Habitat, São Paulo, n. 12, p. 34-35, 1953.

MAX BILL, o arquiteto, a arquitetura, a sociedade. Habitat, São Paulo, n. 14, p. A-B, 1954.

MINDLIN, Henrique Ephim. Modern architecture in Brazil. Rio de Janeiro: Colibris, 1956.

MOCK, Elisabeth. Built in USA: 1932-1944. New York: The Museum of Modern Art, 1944.

MODERN Architecture: International exhibition. New York: The Museum of Modern Art, 1932.

MUÑOZ, María Teresa. Prólogo. In: HITCHCOCK, Henry-Russell; JOHNSON, Philip. El estilo internacional: arquitectura desde 1922. Madrid: Colegio Oficial de Aparejadores y Arquitectos Técnicos de Madrid, 1984. p. 9-26.

MYERS, Irving Evan. Mexico's modern architecture. New York: Architectural Book Publishing Company, 1952.

NIEMEYER, Oscar. Minha arquitetura 1937-2005. Rio de Janeiro: Revan, 2005.

NOELLE, Louise. Las casas de Juan O'Gorman: principio y fin. Summa+, Buenos Aires, n. 182, p. 108-115, 2021.

PAPADAKI, Stamo. The work of Oscar Niemeyer. New York: Reinhold Publishing Corporation, 1950.

PÉREZ CARREÑO, Francisca. El Formalismo y el desarrollo de la historia del arte. In: BOZAL, Valeriano (ed.). Historia de las ideas estéticas y de las teorías artísticas contemporáneas. Madrid: Visor, 1996. v. 2, p. 189-201.

PÉREZ OYARZUN, Fernando (org.). Le Corbusier y Sudamérica: viajes y proyectos. Santiago de Chile: Pontificia Universidad Católica de Chile, 1991.

POMIAN, Krzysztof. Coleção. In: Memória-Historia. Lisboa: Imprensa Nacional, 1984. p. 51-86. (Enciclopédia Einaudi, v. 1). 
POMIAN, Krzysztof. Collectors and curiosities: Paris and Venice, 1500-1800. Cambridge: Polity Press, 1990.

PREZIOSI, Donald. The art of art history: a critical anthology. New York: Oxford University Press, 2009.

RAHMAN, Mohammed H. A. Introdução. In: Enciclopédia dos Museus: Museu Egípcio Cairo. São Paulo: Melhoramentos, 1969. p. 9-15.

REAL, Patricio del. Building a continent: MoMA's Latin American since 1945 exhibition. Journal of Latin American Cultural Studies, [s. l.], v. 16, n. 1, p. 95-110, 2007. Doi: <https://doi. org/10.1080/13569320601156803>.

REAL, Patricio del. Para caer en el olvido: Henry-Russell Hitchcock y la arquitectura latinoamericana. Block, Buenos Aires, n. 8, p. 48-57, 2011.

REAL, Patricio del. Building a continent: the idea of Latin American architecture in the early postwar. 2012. Tese (Doutorado em Filosofia) - Columbia University, New York, 2012.

SANTOS, Cecilia Rodrigues dos; PEREIRA, Margareth Campos da Silva; PEREIRA, Romão Veriano da Silva; SILVA, Vasco Caldeira da. Le Corbusier e o Brasil. São Paulo: Tessela, 1987.

SEARING, Helen. Henry-Russell Hitchcock: the architectural historian as critic and connoisseur. Studies in the History of Art, v. 35, Symposium Papers XIX: The Architectural Historian in America, p. 251-263, 1990.

SEGAWA, Hugo. Arquitectura latinoamericana contemporánea. Barcelona: Gustavo Gili, 2005.

SEGRE, Roberto. The territorial and urban condition of Latin American architecture. In: SEGRE, Roberto; KUSNETZOFF, Fernando (eds.). Latin America in its architecture. New York: Holmes \& Meier Publishers, 1981.

TOCA, Antonio (ed.). Nueva arquitectura en América Latina: presente y futuro. México, DF: Gustavo Gili, 1990.

TORRENT, Horacio. Latinoamérica, las arquitecturas, las exposiciones, las revistas, las ideas: MOMA 1955. In: CONGRESO INTERNACIONAL LAS EXPOSICIONES DE ARQUITECTURA Y LA ARQUITECTURA DE LAS EXPOSICIONES, 8-9 mayo 2014, Pamplona. Actas [...]. Pamplona: Escuela Técnica Superior de Arquitectura Universidad de Navarra, 2014. p. 81-92.

TORRENT, Horacio. Cristal opaco. La arquitectura latinoamericana como categoría historiográfica. In: MONDRAGÓN, Hugo; MEJÍA, Catalina (eds.). Sudamérica moderna: objetos, edificios, territorios. Santiago de Chile: ARQ, 2015. 
TORRENT, Horacio. O sonho e a realidade: unidad estilística y dispersión urbana. In: ZEIN, Ruth Verde (org.). Caleidoscópio concreto: fragmentos de arquitetura moderna em São Paulo. São Paulo: Romano Guerra, 2017. p. 379-414.

Artigo apresentado em: 18/02/2021. Aprovado em: 05/07/2021.

\section{(cc) BY}

All the contents of this journal, except where otherwise noted, is licensed under a Creative Commons Attribution License 